\title{
Kalkınma Planlarında Vergi Politikaları (Hedefler-Gerçekleşmeler,1963-2016)
}

Mahmut KÜÇÜKOĞLU ${ }^{1}$

\section{Özet}

Kalkınma planları; ekonomik ve sosyal faktörler arasındaki ilişkileri, uzun vadel bütünleştirici bir yaklaşımla ele alan, kamu kesimi için emredici, özel kesim için de orta ve uzun vadede yol gösterici, hukuki ve teknik şartlara sahip olan makro ölçekteki planlardır. Planlarda amaç, ekonomik ve sosyal yapının planda öngörülen süre sonunda belirlenen hedeflere ulaşmasını sağlamaktır. Kalkınma Planları ile, ekonomik büyüme ve kalkınmayı sağlayarak kişi başına düşen milli gelirin ve istihdamın artmasını sağlamak, bölgelerarası dengesizliği ortadan kaldırmak gibi ekonomik hedeflerle birlikte; toplumun eğitim ve sosyal açıdan gelişmesini sağlamak, bilim ve teknolojideki yeniliklere sahip olmak, dünya ülkeleri ile karşılıklı iyi ilişkiler kurmaya çalışmak gibi ekonomik olmayan hedefler de gerçekleştirilmeye çalışılmaktadır.

Vergi politikalarında hedeflere ulaşabilmek için kamu gelir ve harcamalarında kalitenin artırılması, vergi mevzuatının sade ve anlaşılabilir hale getirilmesi, vergi tabanının genişletilmesi, vergilemenin daha adil olması, kayıt dıșılıkla mücadele, kurumlar arası koordinasyon ve veri paylaşımının arttırılması, vergilemenin mali fonksiyonunun gerçekleşmesi için büyük önem arz etmektedir.

Bu çalışmada, Türkiye'nin ekonomik, sosyal ve siyasi dinamiklerini etkileyen kalkınma planları kısaca tanıtılmakta, daha sonra bu planlarda hedeflenen vergi politikaları ile ortaya çıkan sonuçlar karşılaştırılarak bir ülkenin mali görünümünü düzenleyen en önemli politika araçlarından biri olan vergi politikalarının etkinliğine yönelik değerlendirmelerde bulunulacaktır.

Anahtar Kelimeler: Kalkınma Planı, Vergi Politikası, Vergi Yapısı

\section{Tax Policy in the Development Plan (1963-2016)}

\section{Abstract}

Development plans; The relationship between economic and social factors, long-term integrative approach in the field, is mandatory for the publics ector, but also medium and long-term guidance for the private sector, with legal and technical conditions are plans in macro scale. The objective of the plan is to ensure the attainment of the objectives set out at theend of the period prescribed in the economic and social structure of the plan with Development Plans, the national income per person by providing economic growth and development and provide employment to increase, interregional disparities with economic objectives, such as to eliminate; to ensure the development of education and social point of view, to have innovation in science and technology, such as work to establish good relations with the other countries of mutual non-economic objectives are tried to be realized.

Improving the quality of public revenue and expenditure in order to achieve the objectives of tax policy, bringing the tax laws simple and comprehensible, broadening the tax base, taxation to be more fair, informality struggle, increasing inter-agency coordination and data sharing, taxation is of great importance for the realization of financial function .

In this study, Turkey's economic, briefly introduced development plans affecting social and political dynamics, the none of these plans in targeted tax policies, with the result that regulate the financial outlook of a country comparison of the most important policy tools will be made in the assessment of the effectiveness of the tax policy.

Keywords: Development Plan, TaxPolicy, TaxStructure

\footnotetext{
${ }^{1}$ Yrd. Doç. Dr. Harran Üniversitesi, Öğretim Üyesi, mkucukoglu@harran.edu.tr
} 


\section{Giriş}

Kalkınma sorunlarına çözüm arayan gelişmekte olan ülkeler, planlı bir ekonomi ile bu hedefin gerçekleşeceğine inanarak plan dâhilinde kalkınma modelini uygulamaktadırlar.

Kalkınma planları; genel ekonominin tümünü, ekonomik ve sosyal faktörler arasındaki ilişkileri, uzun vadeli entegre bir perspektifle ele alan, kamu kesimi için emredici, enerji, vergi ve kredi bağışıklıklarıyla özel kesim için de orta ve uzun vadede yol gösterici, hukuki ve teknik şartlara haiz makro planlardır. Planlarda amaç, ekonomik ve sosyal yapının planda öngörülen süre sonunda hedeflenen düzeye ulaşmasını sağlamaktır. Bu çerçevede, ekonomik büyümeyi sağlayarak kişi başına düşen geliri ve istihdamı artırmak, gelir dağılımı ve bölgelerarası dengesizliği gidermek, ödemeler bilançosu açıklarını azaltmak gibi ekonomik hedeflerle birlikte; toplumun refah düzeyini artırmak, eğitim düzeyini yükseltmek, bilim ve teknolojiyi geliştirmek, dış âlem ile sağlıklı ilişkileri sürdürmek gibi ekonomik olmayan birçok hedef gerçekleştirilmeye çalışılmaktadır (Takım, 2011: 155).

Toplumların sosyal ve iktisadi gelişmesi ile birlikte devletin faaliyetleri genişlemekte ve kamu hizmetlerine talep artmaktadır (Korkmaz, 1982:1). Kamu hizmetlerine olan talebin karşılanabilmesi ve genişleyen devlet faaliyetlerinin finansmanının karşılanabilmesi için de kamu gelirlerinin sağlanmasına ihtiyaç vardır. Devletin kamu harcamalarının en temel kaynağını vergiler oluşturmaktadır. Vergileme, kanun teklif ve/veya tasarısının hazırlanmasından başlayarak mükellefin vergiyi ödemesine kadar geçen uzun bir süreci içermektedir (GencelKuru, 2012: 29). Vergileme, bir yandan adaleti gözetirken, diğer yandan etkinliği sağlamalı ve aynı zamanda kolaylıkla uygulanabilir olmalıdır.

Günümüzde vergiler kamu harcamalarının en önemli finansman kaynağı olarak önemini her geçen gün arttırmakta, bir yandan da ekonomik ve sosyal politikaların önemli bir uygulama aracı haline gelmiş bulunmaktadır. Belirlenen politika kapsamında hedef mal, hizmet, kişi, sektör veya alan üzerinde farklı oran ve/veya miktarda vergi uygulanmak suretiyle karar alıcıların tercihleri üzerinde etkili olunmaya çalışılmaktadır. Bu kapsamda, gerek ülke içinde gerekse de uluslararası boyutta vergi önemli bir politika aracı haline gelmiş bulunmaktadır.

Türkiye önümüzdeki yıllarda dünyanın en büyük ilk on ekonomisi arasına girmeyi hedeflemektedir. Bu hedefe ulaşmada önemli bir rol oynayacak olan maliye politikalarının ve özelde de vergi politikalarının ülke kaynaklarının etkin ve verimli kullanılmasını sağlayacak şekilde belirlenmesi ve uygulanması hayati önem taşımaktadır. $\mathrm{Bu}$ amaçla, vergi sisteminin modern vergileme ilkelerine uygun olarak şekillendirilmesi; vergi politikasının ise kamu harcamalarına kaynak oluşturmanın yanında ekonomik kalkınmayı desteklemeye yönelik olarak üretimi, büyümeyi, istihdamı artırmak ve gelir dağılımı adaletsizliğini azaltmak gibi fonksiyonları da yerine getirecek şekilde oluşturulması gerekmektedir (Kalkınma Bakanlığı, Vergi Ö.İ.K, 2014:XIV).

Ülkemizde gelir dağılımındaki adaletsizlikler ve vergi yükünün adil olmaması Türkiye'de şu ana kadar uygulanan vergi politikalarının sorunlu 
olduğunu ve etkin bir vergi politikasının uygulanmasının gerekli olduğunu göstermektedir.

$\mathrm{Bu}$ nedenle, ülkemizde özellikle kalkınma planları ile birlikte vergi politikalarının tarihsel süreci değerlendirilmeli ve vergilemede aksayan yönler tespit edilerek, verginin sosyal, ekonomik ve mali amaçları yönünden amaçlarına ulaşabilmesi için çözüm yolları bulunmalıdır.

\section{Türkiye'de Kalkınma Planları ve Vergi Yapısı}

Kalkınmanın amacı, insanların refahını artırmak, hayat standartlarını yükseltmek, temel hak ve özgürlüklerini güçlendirerek adil, güvenli ve huzurlu bir yaşam ortamı tesis etmek ve bunu kalıcı kılmaktır.

Türkiye'de planlama fikri 1930'lu yıllarda hazırlanan Sanayi Planları ile başlamış, Devlet Planlama Teşkilatının kurulduğu tarihten günümüze kadar on adet Beş Yıılık Kalkınma Planı hazırlanmış ve uygulamaya konulmuştur. Planların iktisadi felsefeleri ve yaklaşımları kapsamında; 1960 öncesi planları: devletçi, kısmi, 1960-1980 planları: karma ekonomi, bütüncül, 1980-2000 planları: liberal, stratejik olarak nitelendirilebilir. 1980 öncesinde sanayileşmede "ithalat ikamesi politikaları", 1980 sonrası ise "açık ekonomiye geçiş" yönlendirici olmuştur.İlk yıllardaki Kalkınma Planları kamu kesimi için "emredici” özel kesim için de " yol gösterici” niteliğindedir. Kamu kesiminin Planlara uyumu yasalar çerçevesinde olup, özel sektör ise özendirilmiş ve teşvik edilmiştir. Kamu kesiminin uygulama alanı ve yaptırım gücü çok daha fazla olduğundan kalkınmada kamu kesimi daha büyük bir paya sahip olmuştur (Özdemir,2014: 10).

Türkiye'de planlı ekonomi döneminde uygulanan vergi politikalarının, hazineye gelir sağlama gibi geleneksel fonksiyonlarının yanında, kaynak dağılımında etkinliği sağlama gibi ikinci bir görev üstlendiği gözlenmiştir. $\mathrm{Bu}$ çerçevede, birinci beş yıllık planda vergi politikası ile ilgili iki temel düşünce benimsenmiştir. Birincisi, vergi gelirlerinin kamu harcamaları için planın öngördüğü artışı karşılayacak düzeyini tutturmak, ikincisi ise tasarrufları ve yatırım arzusunu teşvik edecek vergi sistemini oluşturmaktır. Planda, vergi sisteminde etkinliği sağlamak üzere vergilerin gelir esnekliğinin artırılması, verginin tabana yayılması ve sektörel düzeyde vergi yükü dengesizliklerin giderilmesi önerilmiştir (Takım, 2011: 160).

Vergi yapıs1, bir ülkede toplanan vergilerin kompozisyonunu ve farklı kaynaklar arasındaki dağılımını ifade etmektedir. Vergi türleri ile her bir vergi türünden elde edilen vergilerin toplam vergi gelirleri içerisindeki ağırlığı vergi yapısını belirleyen temel değişkenlerdir.

Türkiye'de vergi yapısı son 50 yılda büyük bir değişim göstermiştir. Sıklıkla yaşanan ekonomik krizler ve bu krizler sebebiyle kamu kesiminin kısa vadede ihtiyaç duyduğu yüksek oranlardaki finansman ihtiyacına ilâve olarak $\mathrm{AB}$ ile devam eden üyelik süreci, küreselleşme ve beraberinde gelen uluslararası alandaki gelişmelerin ülkemiz vergi sisteminin şekillenmesinde önemli etkileri olduğu görülmektedir. 
$\mathrm{Bu}$ dönemde, temel olarak gelir ve kazanç ile mülkiyet üzerinden alınan vergilerin payı azalırken, sosyal güvenlik primlerinin payı artmıştır. Mal ve hizmetler üzerinden alınan vergilerin payı ise 1965 'te yüzde 54 iken, 1980-2001 arasındaki dönemde bütçe dışı fonların yoğun bir şekilde kullanılması nedeniyle yüzde 28 seviyelerine kadar düşmüş; bu fonların kaldırılmasından sonra ise tekrar artarak 2011 yılında yüzde 46 seviyesine ulaşmıştır. Gelir ve kazançlar üzerinden alınan vergilerin toplam vergi gelirleri içerisindeki payı 1965 'te yüzde 29,6 iken, 2011 yllında yüzde 21,3'e gerilemiştir. Bu değişimin temel nedeni, gelir vergisinin payının 1965 'ten günümüze yaklaşık olarak yüzde 45 oranında gerilemiş olmasıdır. Kurumlar vergisi ise aynı dönemde ters yönde hareket etmiş ve vergi gelirleri içindeki payı yüzde 4,8'den yüzde 7,6'ya kadar yükselmiştir. Bir başka deyişle, toplam vergi gelirleri içinde gelir vergisinin payı azalırken kurumlar vergisinin payı artış göstermiştir. Bu durumun temel nedenlerinden bir tanesi gelir vergisi oranlarının önemli ölçüde aşağı çekilmiş olmasıdır. En yüksek vergi oranı 1980'li yılların başındaki yüzde 75 seviyesinden zaman içinde aşağı yönlü bir eğilim izleyerek 2005 yılında yüzde 40'a, 2006 yılında ise yüzde 35'e gerilemiştir. Yine, en düşük vergi oranının da 1981 yılındaki yüzde 40 seviyesinden 2006 y1lında yüzde 15'e indiği görülmektedir. Ayrıca, 1999-2005 yılları arasında ücret gelirlerine 5 puanlık bir vergi avantajı sağlandığı unutulmamalıdır. Benzer şekilde, 1981 yılında 7 olan vergi dilimi sayıs1 1986'da 6'ya, 2005'te 5'e ve en son 2006 yılında da 4'e indirilmiştir. Gelir vergisinin payındaki düşüşün diğer önemli nedenleri olarak; gerçek kişilerin gelirlerinin milli gelirdeki artışa paralel olarak kayıt içine alınamaması, ayırma kuramı çerçevesinde özellikle menkul sermaye gelirlerinin düşük oranda vergilendirilmesi ile istisna ve muafiyet uygulamalarının kapsamının genişletilmesi sayılabilir. Kurumlar vergisinin payının artmasının önemli nedenlerinden birisi ise ülkemizde bu dönemde kurumsallaşmanın artmış olmasidir.

Vergi gelirleri içerisinde en büyük artış sosyal güvenlik primlerinde yaşanmıştır. 1965-2008 yılları arasında sosyal güvenlik primlerinin toplam vergi gelirleri içerisindeki payı, kriz dönemleri hariç istikrarlı bir şekilde artarak yüzde 5,9 'dan yüzde 25 'e kadar yükselmiştir. 2008 yılında sigorta primi işveren payında yapılan 5 puanlık indirimin ardından bu oran bir miktar düşmüş ancak 2011 yılında artarak yüzde 26,7'ye kadar yükselmiştir.

Türk vergi yapısında bu dönemde gerçekleşen dikkat çekici bir gelişme de 1995 'te yüzde 19'a kadar yükselen diğer vergilerin payının 2011 yılı itibarıyla yüzde 1,9'a kadar düşmüş olmasıdır. 1980 ve 1990'l1 yıllarda vergi gelirleri içinde önemli yer tutan diğer vergilerin büyük bölümü genel ve katma bütçeli kuruluşların fon gelirlerinden kaynaklanmaktadır.

Ülkemiz vergi yapısı OECD ülkelerinin genelindeki vergi yapısından bazı alanlarda önemli farklılıklar göstermektedir. 1965-2010 yılları arasındaki dönemde OECD ülkelerinde sosyal güvenlik primleri ile genel tüketim vergilerinin payı artarken, özel tüketim vergilerinin ve mülkiyet üzerinden alınan vergilerin payı azalmış, diğer vergilerde ise önemli bir değişiklik olmamıştır. Buna karşılık ülkemizde sosyal güvenlik primlerinin payı benzer bir şekilde artarken, gelir vergileri ve mülkiyet üzerinden alınan vergilerin payı azalmış, tüketim vergileri ise yaklaşık yüzde 45 oranındaki yüksek seviyesini korumuştur. 1965-2010 yılları arasındaki dönemde OECD ülkelerinde gelir vergisinin toplam vergiler içindeki 
payı ortalama yüzde 25 seviyesinde gerçekleşmiştir. Aynı dönemde Türkiye'de ise gelir vergisinin pay1 yüzde 25 'ten yüzde 14 'e kadar gerilemiştir. Bu durum, Türkiye'de toplam vergi gelirleri içerisinde gerçek kişilerden alınan vergilerin payının OECD ortalamasının çok altında olduğunu göstermektedir. Kurumlar vergisi açısından ise ülkemizin son y1llarda OECD ortalamasını yakaladığı görülmektedir. OECD ülkelerinde kurumlar vergisinin payı istikrarlı bir şekilde yüzde 8 seviyelerinde gerçekleşirken, Türkiye'de bu oran ilgili dönemde yüzde 4,8'den yüzde 7,6'ya yükselmiştir.

Diğer taraftan, OECD ülkeleri ortalamasında tüketim vergilerinin toplam vergiler içindeki payı son 40 yıllık dönemde istikrar kazanarak yüzde 31 seviyesinde gerçekleşirken, Türkiye'de genel olarak yüzde 40 seviyelerinde seyretmiş ve 2011 yılı itibarıla yüzde 44,1'e kadar yükselmiştir. Ülkemizde 2000 yılı sonrasında tüketim vergilerinin payının hızla artmasının temel nedeni, gelir etkisinin kısa sürede ortaya çıkması ve tahsilat kolaylığı nedenleriyle kamuya finansman sağlamada tüketim vergilerinin tercih edilmesidir (Kalkınma Bakanlığı, Vergi Ö.İ.K, 2014: 3-4)

Küreselleşme sürecinin vergi politikaları üzerindeki en önemli etkisi, vergi yapısındaki değişim olarak ortaya çıkmaktadır. Önerilen vergi politikaları, vergi sistemleri içinde dolaysız vergilerden dolaylı vergilere doğru bir dönüşümü beraberinde getirmektedir. Gelişmekte olan ülkelerde vergi yapısındaki dönüşüm vergi yükü dağılımını, sermaye gelirleri lehine çevirmektedir. Bunun yanı sıra küreselleşme ile birlikte sermayenin uluslararası dolaşımının artması, onun yüksek vergi yükü alanlarından düşük vergi yükü alanlarına kayışına neden olmaktadır (Önder, 2003: 256).

Yabancı sermaye girişini kolaylaştırmak ya da kaçışını engellemek için sermaye gelirleri üzerindeki vergi yükünün azaltılması var olan kamu açıklarının giderek artışına neden olmaktadır. Böylece küreselleşme süreciyle paralel biçimde kamu gelirleri içinde borçlanmanın payı yükselmektedir (Karg1-Özuğurlu, 2007: 279).

Birçok dünya ülkesinde olmadığı gibi Türk vergi yapısı da mükemmel değildir; eksik ve kusurları vardır. Bunların bazıları hatta çok önemlidir ve mutlaka düzeltilmeleri gerekir. Ancak bir kısım kusurlarına rağmen, vergi sistemimizin bütünü ve genel yapısı itibariyle -uygulamadaki eksik ve kusurlar hariç olmak üzere-çağdaş vergicilik anlayışına uygun, ileri sayılabilecek bir seviyeye eriştiğini de kabul etmek gerekir (Nadaroğlu, 2000: 414).

\subsection{Kalkınma Planı Tanımı ve Önemi}

Kalkınma, iktisadi yapıdaki çok bölümlü değişikliklere dayanmaktadır. $\mathrm{Bu}$ değişiklikler yanında insanların yetiştirilmesi, zihniyetteki yenilenme de önemlidir. Yatırım çabaları, halk eğitiminin ele alınması ve millette kalkınma özlemlerini kamçılayacak bir heyecanın, arzunun diri tutulması ile beraber yürümelidir. Kalkınma yalnızca son derece ehil bir teknik kadronun değil, bir milletin eseri olabilir. Milli potansiyel ancak bu kadro ile harekete geçirilebilir. Bu bütünleşme kalkınmayı gerçek kılar (Güner,1978: 78-79). 
Belirli bir amacı gerçekleştirmek için alınan önlemler bütününe planlama denir.

"Kalkınma planlaması, uzun dönemli kalkınma politikasının belli kurallara göre düzenlenmesi demektir. En geniş anlamıyla kalkınma planlaması bir ülkede geçerli ekonomik, sosyal ve siyasal değer yargıları 1şı̆̆ında, belirli bir dönemde toplumun ulaşmak istediği sosyo-ekonomik amaçlara ve sayısal olarak belirlenmiş hedeflere en uygun bir biçimde varmak için, kaynakların belirli organlar tarafindan yönetilmesi sürecidir diyebiliriz."

Kişi başına düşen milli gelirin artması yanında, genel olarak üretim faktörlerinin etkinlik ve miktarlarının değişmesi, sanayi kesiminin milli gelir ve ihracat içindeki payının artması gibi yapısal değişiklikler, kalkınmanın temel öğesidir.

Özellikle İkinci Dünya Savaşı sonrası dünyada, azgelişmiş ülkelerin ekonomilerini planlayarak kalkınmalarını hızlandırabilecekleri, savaşın neden olduğu ekonomik olumsuzlukları giderebilecekleri ve gelişmiş ülkelerle olan gelişmişlik farkını kapatabilecekleri görüşü yaygınlaşmış ve uluslararası ekonomik kuruluşlar tarafından da bu yönde öneriler yoğunluk kazanmıştır. Ekonomik süreç konusundaki görüşlerde görülen bu değişme, aslında tüm azgelişmiş ülkelerde hazırlanan planların gerekçesini de açıklamaktadır. Planlı kalkınma tüm azgelişmiş ülkelerde uygulandığı gibi Türkiye'de de İkinci Dünya Savaşı sonrasında uygulanmaya başlanmıştır.

Türkiye'de Kalkınma Plan ve Programları denildiğinde hemen ilk akla gelen, ilki 1963 yılında yürürlüğe konulan ve halen onuncusu uygulanmakta olan Beş Yıllık Kalkınma Planları olmaktadır. Oysa Türkiye'de planlı kalkınma hamlelerininoluşumunun geçmişi Cumhuriyet'in kuruluş yıllarına dayanmaktadır. Aslında, Cumhuriyet öncesinde, yani Osmanlı Devleti'nin son dönemlerindeki sanayinin durumuna da kısa göz atmakta yarar vardır. Bu dönemde sanayi faaliyetlerinin planlanmasına yönelik sayılabilecek faaliyetler; 1913 - 1915 yılarında yapılan "Sanayi Sayımı" ile ülke sanayini canlandırmak amacıyla 1 Ocak 1913 tarihinde çıkarılan "Teşvik-i Sanayi Kanunu Muvakkati”dir. Bu kanun ile toplam değeri 1000 lirayı aşan sanayi tesisleri için beş dönüme kadar bedelsiz arazi tahsisi, makine teçhizat ile ham ve yardımcı maddelerin gümrük vergi ve harçlarından muafiyeti, fabrikaların kurulması ve işletilmesi ile ilgili vergi, resim ve harçlardan muaf tutulması imkânları sağlanmıştır. Bu tarihlerde ordunun ihtiyaçlarını karşılamak üzere bazı yeni yatırımlara rastlanmaktadır" (Özdemir, 2014: 3-7).

1961 Anayasası ilk kez "planlı kalkınma" ilkesine yer vermiş ve Birinci Beş Yıllık Kalkınma Planı hazırlanmış, 20.09.1960 tarih ve 91 sayılı Kanunla Devlet Planlama Teşkilatı (DPT) kurulmuştur. DPT’nin amacı; “ülke kaynaklarının verimli kullanılması ve kalkınmanın hızlandırılması için ülkenin ekonomik, sosyal ve kültürel planlama hizmetlerinin bir bütünlükiçerisinde etkin, düzenli ve süratli olarak yürütülmesini sağlamak" olarak açıklanmaktadır (Öner ve Yıldırım, 2002: 244).

"Devlet Planlama Teşkilatının kurulduğu tarihten bugüne kadar 10 adet Beş Yıllık Kalkınma Planı uygulamaya konulmuştur. Planların iktisadi felsefeleri 
ve yaklaşımları kapsamında; 1960 öncesi planları: devletçi, kısmi, 1960-1980 planları: karma ekonomi, bütüncül, 1980-2000 planları: liberal, stratejik olarak nitelendirilebilir. 1980 öncesinde sanayileşmede "ithalat ikamesi politikaları", 1980 sonrası ise "açık ekonomiye geçiş" yönlendirici olmuştur."

İçinde olduğumuz dünyada daha fazla üretmek ve tüketmek vazgeçilmez bir istek haline gelmiştir. Daha fazla mal ve hizmet üretimi ve bunun toplum tarafindan tüketimi, toplumun yaşam düzeyinin yükseltilmesi ve giderek o toplumun uygar toplumlar arasına katılması demektir. Kalkınma, var olmak isteyen her toplum için kaçınılmaz bir durumdur. Yüksek bir kalkınma hızı ancak iyi bir devlet yönetimiyle mümkün olabilir.

Türkiye'nin uzun vadeli kalkınma amacı, milletimizin temel değerlerini ve beklentilerini esas alarak gerçekleştirilecek yapısal dönüşümlerle dünyada Türkiye'nin uluslararası konumunu güçlendirerek halkın refahını artırmaktır. Bu çerçevede, 2023 yılında Türkiye'nin dünyanın ilk 10 ekonomisi arasına girmesi, GSYH'nın 2 trilyon dolara, kişi başına düşen gelirin 25 bin dolara yükseltilmesi, ihracatın 500 milyar dolara yükseltilmesi, AR-GE harcamalarının GSYIH'nın yüzde 3'üne çıkartılması, işsizlik oranının yüzde 5'e indirilmesi ile birlikte enflasyon oranlarının kalıcı olarak tek haneli rakamlara düşürülmesi hedeflenmektedir.(Kalkınma Bakanlığı, Bölgesel Gelişme Ulusal Stratejisi (2014-2023), 2014: 7)

\subsection{Vergi Politikasının Tanımı ve Önemi}

Devlet, maliye politikasının bir amacı olan ekonomik büyüme ve kalkınmayı gerçekleştirirken çeşitli araçlardan faydalanmaktadır. Bu araçlar; vergi politikası, harcama politikası (bütçe politikası) ve borçlanma politikasıdır. Maliye politikası yukarıda belirtilen araçlardan yararlanarak belirli amaçlara ulaşmaya çalışır. Vergileme politikası, özellikle gelişmekte olan ülkelerde maliye politikalarıaraçlarından biri olarak oldukça etkin bir mali araç olarak görülmektedir (Eker, Altay, Sakal, 1996: 32).

Kamu harcamalarının finansmanı için ne kadar vergi toplanacağı, vergi konularının neler olacağı, vergilemenin zamanı, kimden ve hangi kesimden ne kadar vergi alınacağ 1 , hangi konu ve mükelleflerin vergileme dışıbırakılacağ finansmanda alternatif yöntemlere başvurulup başvurulmayacağı birer "siyasal karar alma" sorunudur. Siyasal karar alma mekanizmasıdiğer maliye politikası değişkenleri üzerinde olduğu gibi vergileme üzerinde de son derece önemli etkilere sahiptir ve seçimlere dayalı bir çevrim ortaya çıkabilir (Gencel-Kuru, 2012: 37).

Vergiler aracıllğıyla; ülkenin genel sosyal, ekonomik ve mali yapısı üzerinde etkili olmak suretiyle, amaçlanan etkiler sağlanmaktadır. Özel üretim ve tüketim kararlarının etkilenmediği bir vergi sisteminin iyi sağlandığı şeklindeki yaklaşım biçimi, yerini; devletin gerektiğinde düzenleyici ve düzeltici kararlar alması yaklaşımına bırakmış olup, günümüzde hemen her ülkede bu anlamda farklı uygulamalar gündeme gelmektedir. Özellikle zorunlu tasarruf ve teşvik edicive yönlendirici vergi politikası içerisinde devlet ekonomik kalkınmayı sağlayıcı yönde etkili olabilmektedir. 
Ekonomik kalkınmanın kendi haline bırakılması durumunda, ekonomilerin yapısında var olan darboğazlar ve kısır döngüler nedeniyle, sakıncalı durumlarla karşılaşılmasına yol açılabilmekte olup, özellikle gelişmekte olan ekonomilerde devletin, ekonomik kalkınma çabasında doğrudan ya dadolaylı uygulamalarla önemli görevleri üstlenmesi gereği ortaya çıkabilmektedir (Akdoğan, 2009: 474481)

Devletin vergi politikası toplam tasarrufu arttırıcı ve ekonomik kalkınmayı sağlayabilecek yatırımları teşvik edici mahiyette olmalıdır. Az gelişmiş ve gelişmekte olan ülkeler genel olarak fakirdir ve toplum bireylerinin ödeme güçleri yetersizdir. Dolayisıyla, vergilere fazla yüklenmek, dar ve sabit gelirli toplum kesimlerini olumsuz etkiler. Ayrıca, ağır vergi yükü; tasarrufları ve yatırımları azaltabileceği gibi teşebbüs gücünü de baltalar. $\mathrm{Bu}$ ise güdülen amaca ters düşen bir vergi politikasının izlenmesine neden olunabilir (Türk, 1975: 270).

Vergiler, bireylerin çalışma arzularını azaltma veya arttırma yönünde de ekonomiyi etkileyebilmektedir. Yani vergiler bireyleri çalışma ile boş durma arasında tercih yapmaya zorlayabilmektedir. Emek arzı üzerine konulan vergiler, insanların emek arz ederek sağladıkları faydayı düşürdüğünden çalışma isteklerini olumsuz etkiler. Vergi nedeniyle geliri azalan birey eski refah düzeyine ulaşabilmek için daha çok çalışabileceği gibi (gelir etkisi), daha az çalışarak ödemek zorunda olduğu vergiyi azaltma yolunu da seçebilmektedir (ikame etkisi). Vergilerin çalışma kararları üzerindeki etkileri değerlendirilirken, emek arzının ücretin bir fonksiyonu olduğu dikkate alınmalıdır. Bu kapsamda; vergi indirimlerinin maaş ve ücret artışı yoluyla çalışma isteğini arttıracağısonucuna ulaşılabilmektedir. Bu durum özellikle gelir üzerinden alınan vergilerde daha fazla görülmektedir (Temiz, 2008:7)

Ekonomik büyüme ve kalkınma günümüzde hem gelişmiş hem de gelişmekte olan ülkelerde devletin temel makroekonomik amaçlarından biri olarak kabul edilir. Bununla birlikte, gelişmiş ülkeler için öngörülen kalkınma politikaları ile gelişmekte olan ülkeler için öngörülen kalkınma politikaları, ülkelerin yapısal özellikleri(işsizlik, fiyat istikrarı vb.) nedeniyle farklılık gösterebilmektedir. Gelişmekte olan bir ülkede maliye politikasının temel amacı istikrarlı bir ortam temin edilmek suretiyle kalkınmanın sağlanmasıdır.

Gelişmiş bir para piyasasından yoksun ve iç kaynak yetersizliği ile karşı karşıya olan gelişmekte olan ülkelerde, kamu kaynaklarının seferberliği için temel araç vergi politikalarıdır. Vergileme, hem gerçekleştirdiği doğrudan katkılar, hem de kontrol ve teşvik açısından yarattığ dolaylı etkiler nedeniyle ekonomik kalkınmanın finansmanının en önemli kaynağıdır. Bu kapsamda; Vergi sisteminin, kaynakları özel sektör içinde düşük öncelikli kullanımlardan, yüksek öncelikli kullanımlara doğru aktarması sağlanmalıdır. Bununla birlikte, gelişmekte olan ülkelerde vergi politikasının, kalkınmanın önemli bir finansman aracı olarak, girişimcilikten kaynaklanmayan gelirlerin etkin olarak vergilendirilmesine yönelmesi ve üretimde bulunan ve verimli yatırımlar yapan özel sektöre yeterli teşvikleri sağlaması gerekir (Siverekli, 2003: 100). 
Kalkınmanın finansmanı amacıyla yapılan girişimlerin desteklenmesinde vergi politikasının doğru ve vergileme tekniklerinin iyi olmasının büyük önemi vardır. Kalkınmanın Finansmanı; vergi politikası içinde, verginin yapısal yetersizlikleri nedeniyle yaşam düzeyinin gerilemesine neden olabilir. Vergi kaçakçı1lı̆̆, vergi kanunlarındaki boşluklar, rezervlerin yeterince değerlendirilememesi, denetim zayıflı̆̆ toplama maliyetinin yüksek olması ve kaynakları etkin kullanamama gibi etkenler, izlenen vergi politikasının ekonomik kalkınma açısından başarısını olumsuz yönde etkileyecektir.

\section{Kalkınma Planlarında Vergi Politikalarına İlişkin Hedefler ve}

\section{Gerçeklessmeler}

Ekonomik kalkınma, ülkenin ekonomik, toplumsal, siyasi yapılarının değișerek insan yaşamının maddi ve manevi alanda ilerlemesi ve toplumsal refahın artmasıdır. Bu bakımdan kalkınma, ölçümlere dayalı olan ve GSMH' daki hızlı artışla belirlenen ekonomik büyümeyi içermekle birlikte, ekonomik ve sosyal değişimleri de kapsamaktadır.

Diğer ülkelerde olduğu gibi bizim ülkemizde de vergiler kamu gelirlerinin büyük bir kısmını oluşturmaktadır. Dolayısıyla, etkin vergilemenin gerekliliği, ekonomi politikalarının doğru yönlendirilebilmesi açısından önem kazanmaktadır. Ülkemizde gelir dağılımı sorunları ve adil olmayan vergi yükü dağılımı vergi politikasının etkin olmadığını göstermektedir. Türkiye'de şu ana kadar uygulanan vergi politikaları, ekonomik ve sosyal açıdan olumsuz bir görüntü arz etmektedir.

$\mathrm{Bu}$ kısımda; ülkemizde uygulanan vergi politikalarını, planlı kalkınma anlayışının benimsendiği 1960'lı yıllardan başlayarak ve ilki 1963 yılında hazırlanan 1.BYKP ile ele alarak, 1963 ile 2016 yılları arasında uygulanmış on adet

Beş Yıllık Kalkınma Planlarında Vergi Politikalarına ilişkin hedefler ve gerçekleşmelerin neler olduğu hususu üzerinde durulacaktır.

1. Birinci Beş Yı1lık Kalkınma Planı (BBYKP): 1963-1967

2. İkinci Beş Yıllık Kalkınma Planı (İBYKP): 1968-1972

3. Üçüncü Beş Yıllık Kalkınma Planı (ÜBYKP): 1973-1977

4. Dördüncü Beş Yıllık Kalkınma Planı (DBYKP): 1979-1983

5. Beşinci Beş Yıllık Kalkınma Planı (Beşinci BYKP): 1985-1989

6. Altıncı Beş Yıılık Kalkınma Planı (ABYKP): 1990-1994

7. Yedinci Beş Yıllık Kalkınma Planı (YBYKP): 1996-2000

8. Sekizinci Beş Yıllık Kalkınma Planı (SBYKP): 2007-2013

9. Dokuzuncu Beş Yıılık Kalkınma Planı (DBYKP): 2001-2005

10.Onuncu Beş Yıllık Kalkınma Planı (OBYKP): 2014-2018 


\subsection{BYKP'da Genel Hedefler ve Gerçekleşmeler (1963-1967)}

Birinci Beş Yıllık Kalkınma Planının iktisadi ve sosyal hedeflerine ulaşabilmesi, vergi sistemimizin bugün iyi işlemeyen yönlerinin düzeltilmesine ve bütün sistemin ahenkli bir șekilde ișlemesine bağlıdır. Kamu harcamalarının finansmanında en önemli yeri genel bütçe vergi gelirleri tutmaktadır. Planın finansman ihtiyaçlarının genişlemesine paralel bu gelirlerin de yükselmesi gerekmektedir. Bu yükselme bir taraftan ekonomimizin geliştirilmesinden doğacak normal inkişaf, diğer yandan da sistemde yapılacak ıslahat ile sağlanacaktır denilmektedir (Aydın, 2009: 171).

Birinci Beş Yıllık Kalkınma Planının temel iktisadi hedefi, Türk ekonomisinde yüzde 7 nispetinde bir gelişme sağlamaktır. Yapılan ön çalışmalar Türk ekonomisinin yüzde 7 nispetinde büyümesi için gerekli iç kaynakları yaratma imkânlarının var olduğunu göstermiş, beş yıllık plânda bu kaynakları harekete geçirmek ve gelişme hedeflerine yöneltmek için gerekli dış finansmanın sağlanacağı öngörülmüştür.

Plan döneminde Kamu gelirlerinin yılda yüzde 9,4 oranında artmas hedeflenmektedir. Dönem sonunda planda öngörülen hedeflere büyük ölçüde ulaşıldı̆̆ı görülmektedir.1963-1967 döneminde102.105 milyon tl vergi toplanması hedeflenmiş, dönem sonunda 92.222 milyon tl vergi hasılatı gerçekleşerek plan hedefleri \% 90.3 oranında gerçekleşmiştir (3.BYKP, 1972: 40).

1950-1960 döneminde genel bütçeye giren vergiler gayrisafi millî hasılanın ortalama yüzde 11 - 12 sini teşkil etmiştir. Bu oranın plan dönemi sonuna kadar, vergi gelirlerinin gayrisâfi millî hasılaya oranının yüzde 17.3 e kadar yükselmesi gerekmektedir. Vergi gelirlerinde gerekli olan bu yükselmenin ekonomik hayattaki gelişme ve vergi sisteminde yapılacak reformlar ile sağlanacağ $\mathrm{Bu}$ dönemde yapılan gelir tahminleri kalkınma planının finansman ihtiyaçları dikkate alınarak yapılmıştır (1.BYKP,1963: 117-127).

Planlı kalkınma uygulamasının ilk yılları olmasından doğan güçlüklere rağmen, 1962 - 1966 döneminde, yılda ortalama yüzde 6,5 seviyesinde bir gelişme hızının sağlandığı görülmektedir (2.BYKP,1968-1972: 66).

\subsection{BYKP'da Genel Hedefler ve Gerçekleşmeler (1968-1972)}

İkinci Beş Yıllık Plan döneminde izlenecek vergi politikasının temel amacının, kabul edilmiş bulunan ekonomik ve sosyal hedeflere uygun olarak planın finansmanını ekonomik istikrarsızlığa yol açmadan adaletli olarak sağlamak ve tasarrufları verimli yatırımlara yöneltmek olacağı ifade edilmektedir.

Plan döneminde planda öngörülen hedeflere büyük ölçüde ulaşıldığ1 görülmektedir.1968-1972 yılları arasındaki dönemde 156.421 milyon TL vergi toplanması hedeflenmiş, dönem sonunda 145.453 milyon TL vergi hasılat1 gerçekleşerek plan hedefleri \% 93 oranında gerçekleşmiştir (3.BYKP, 1972: 40).

Kabul edilmiş bulunan yılda ortalama yüzde 7 büyüme hedefi tasarruf ve yatırımların öngörülen seviyelere çıkarılması yanında, yatırımların üretim faaliyetleri arasında tespit edilen şekilde dağıtılmasını da gerektirmektedir. 
Plan döneminde gayrisafi milli hasılanın ortalama yüzde 30 unu teşkil edecek kamu yatırım, cari ve transfer harcamalarının enflasyonist olmayan yollardan karşılanması gerektiği bu sebeple vergilemenin gerekli kaynakların elde edilmesinde başlıca vasıta olarak kullanılacağı belirtilmektedir.

İkinci Beş Yıllık Plan döneminde izlenecek vergi politikasının temel bir amacı da gelirin fertler arasında daha adil bir şekilde dağılmasına yardımcı olmaktır. Aynı amaçla mükelleflerin vergi karşısında eşitliği sağlanacaktır. Bugünkü sistemin, uygulama aksaklıkları, vergilemedeki hata ve noksanlar ve ekonomik yapının çok ileri vergi tekniklerini kullanmaya elverişli olmaması sebebiyle vergi yükünün fert ve sektörler arasında sosyal adalete uygun olarak dağıtılmasını istenen ölçüde sağlayamadığı tespiti yapılarak, bir taraftan vergi ödeme gücüne göre vergi alınarak dikey vergi eşitliğinin sağlanması, diğer taraftan da eşit güçleri eşit şekilde vergilendirerek yatay vergi eşitliğini sağlamakla beraber sosyal adalet açısından bazı ayırımların yapılmasına da yer verilmesi için çaba göstermek gerektiği, vasıtalı vergilerin tersine müterakki etkilerini azaltacak tedbirlerin alınması yanında bu yolun mevcut sistemde ekonomik yapıdan gelen etkilerle sınırlı oluşu sebebiyle sosyal adaleti gerçekleştirmede en etken bir araç olan vasıtasız vergilerin toplam vergi gelirleri içindeki payının artırılmasına çalışılacă̆ 1 ifade edilmektedir.

Plan döneminde mevcut vergi sistemine ilişkin yapılan tespitler aşağıdaki şekildedir:

Vergi sistemi yeterli ölçüde esnek değildir. Birinci Plan döneminde her yıl yeni finansman zorlukları ile karşılaşılmış ve her yıl gelirleri artırıcı yeni tedbirlerin alınması zorunlu olmuştur.

Vergi sistemi içinde vasıtalı vergilerin payı yüzde 70 seviyesindedir. $\mathrm{Bu}$ da vergi yükünün dağılımında adalet ilkesinin istenen seviyede gözetilememesine yol açmaktadır.

Tahsil edilecek vasitalı vergilerin 1967 de yüzde 42' sinin, 1972 de ise yüzde 36' sının ithalata bağlı olacağı tahmin edilmektedir. Vergi sisteminin dış ticarete bu derecede bağlı olmasının sakıncalı yönleri mevcuttur.

Güdülecek vergi politikası ile vergi sisteminin etkin bir kaynak dağılımı için gerekli nitelikleri taşıması; kaynakların tüketim yerine Planın teşvik ettiği alanlardaki yatırımlara yöneltilmesi sağlanacaktır. Bu amaçla;

Gümrük Vergisi ile istihsal Vergileri gözden geçirilerek sınai mamullerin maliyetlerine olumsuz etkide bulunan yönleri düzeltilecektir.

İstihsal Vergisinin yerini almak, zere daha ileri bir vergi niteliği gösteren katma değer vergisinin uygulanması hazırlıklarına başlanılacaktır.

Lüks tüketimi vergilemek suretiyle bu mallara olan talep kısılmasını ve bu alanlara yapılacak yatırımların azaltılmasını sağlayıcı yönden tedbirler alınacaktır.

Yatırımların ihracata dönük, maliyet yapısı ile dış pazarlarda rekabet gücü, kazanabilecek olan sanayi dallarına yönelmesi için sistem içinde mevcut vergi teşvik tedbirleri gözden geçirilecektir. 
Yatırımların bölgelerarası denge yönünden gerekli görülen alanlara yapılması için yeni vergi teşvik tedbirleri alınacaktır denilmektedir (2.BYKP,1967: 105-109).

\subsection{BYKP'da Genel Hedefler ve Gerçekleșmeler (1973-1977)}

Üçüncü Beş Yıllık Kalkınma Planı; 1973-1977 yıllarını kapsamaktadır.

III. Plan dönemi için yüzde 7,4 olarak öngörülen büyüme oranı yüzde 6,5 olarak gerçekleşmiştir. Yine aynı dönemde gayrisafi yurt içi hâsılanın (GSYİH) büyüme oranı yılda ortalama yüzde 7,6 olarak hedef alınmış, gerçekleşme yüzde 6,9 olmuştur (4.BYKP,1979: 7).

III. Planda, toplam kamu gelirlerinde yılda ortalama yüzde 11,6 artış olması öngörülmüş, gerçekleşme yüzde 6,3 olmuştur. Bu gelişmeyi özellikle vergi gelirlerindeki gerçekleşmeler etkilemiştir. Toplam vergi gelirlerinin yılda ortalama yüzde 13,0 artması öngörülmüş, ancak yüzde 10,3 olarak gerçekleşmiştir. Dolaysız vergilerde yüzde 15,2 olarak öngörülen yıllık ortalama artış oranı yüzde 16,6 olarak gerçekleşirken, dolaylı vergiler öngörülen ölçüde artırılamamıştır. Dolaylı vergilerin III. Plan döneminde yılda ortalama yüzde 11,7 oranında artırılması hedef alındığ 1 halde, gerçekleşme yılda ortalama yüzde 4,7 oranında olmuş; toplam vergi hedeflerine ulaşılamamasını dolaylı vergi hedeflerindeki geri kalma etkilemiştir (4.BYKP,1979: 86-87).

Planda yer alan vergi politikalarına ilişkin tespitler ve hedefler iseözetle aşağıdaki şekildedir.

Kamu gelirleri sistemi ise sağladığı önemli kaynak artışlarına rağmen uzun vadeli hedefler ile fiyat istikrarının birlikte gerçekleştirilmesinde yeterli olamamıştır. İkinci Plan döneminde vergilerden teşvik ve yöneltme aracı olarak önceki dönemlere göre daha yaygın bir şekilde yararlanılmıştır. Vergi sisteminin gelir artışlarını kendiliğinden takip etmeyi sağlayacak şekilde yaygın bir tabana ve esnekliğe sahip olmayışı ve bunun yanında kamu iktisadi teşebbüslerinin mail durumlarının bozulması sı sık bazı vergilerin nispetlerinde değişiklik yapılması veya Hazine imkânlarının zorlanması sonucunu vermiştir.

1970 İstikrar Programı ile birlikte vergi sisteminde ve daha sonra kamu iktisadi teşebbüslerinin fiyatlarında olumlu düzenlemeler yapılmıştır. Spekülatif karakterli gelirlere yönelen yeni vergiler kabul edilmiş bazı vergilerin kapsamları genişletilmiş ve nispetleri arttırılmıştır. Bu değişikliklerin vergi adaleti yönünden nitelikleri genellikle olumludur. Diğer taraftan, sistem vergi yükünün daha adil bir şekilde dağıtılması açısından da yetersizliğini korumaktadır.

Plan uygulamasını aksatacak ve saptıracak konjonktür hareketlerinin önlenmesi veya asgariye indirilmesi istikrar içinde kalkınmanın gereğidir. $\mathrm{Bu}$ bakımdan maliye politikasının kısa devrede hedefi ekonomide genel dengenin korunmasidır.

Plan döneminde gelir farklarının azaltılmasında kamu harcamalarından yararlanılacak ve vergi sistemi ıslah edilerek vergi yükünün adil bir şekilde dağılması sağlanacaktır. Bu yönden vergi politikasının temel ilkesi ödeme gücüne göre vergilendirmenin gerçekleşmesi ve eşit gelirler arasında sosyal adalet amacına uymayan bir ayırımın önlenmesidir. 
Vergi sisteminin esnekliğini ve sosyal adaleti zedeleyici bir etki göstermekte olan, vergi muafiyet ve istisnaları yeniden gözden geçirilecek, ekonomik, sosyal ve mali amaçlar yönünden muhafazasına lüzum olmayanlar kaldırılacaktır.

Ekonomiyi kısa dönemde konjonktür şartlarına göre düzenleyebilmek amacıyla Bakanlar Kuruluna vergi hadlerini süratle değiştirebilme imkanı verecek kanuni yetkinin sağlanmasına çalışılacaktır.

Gelir vergisi tarifesinde alt ve orta gelir dilimlerinde görülen aşırı ve hızlı müterakkilik yumuşatılacaktır. Bu sebeple doğacak vergi kaybı gelir vergisi sistemi içinde yapılacak değişikliklerle karşılanacaktır.

Katma değer vergisi sistemine geçilecektir.

Vergi sisteminin etkili bir biçimde uygulamaya konulabilmesi ve plan amaçlarına uygun bir politika aracı olarak kullanılabilmesi, Türk vergi idaresinin yeniden düzenlenmesini zorunlu k1lmaktadır, idarenin vergi sistemini etkili bir şekilde uygulayacak yapıya kavuşturulması amacıyla vergicilik hizmetlerinin teknik özelliklerine uygun bir teşkilat düzeni getirilecek, sürekli ve etkili bir kontrol mekanizması kurulacaktır.

Kaynakta tevkif sisteminin yaygınlaştırılması için gerekli tedbirler alınacaktır (3.BYKP,1972: 871-875)

\subsection{BYKP'da Genel Hedefler ve Gerçekleşmeler (1979-1983)}

Dördüncü Beş Yıllık Kalkınma Planı; 1979-1983 yıllarını kapsamaktadır.

Planda yer alan vergi politikalarına ilişkin tesbitler ve hedefler ise özetle aşağıdaki şekildedir.

Dördüncü Plan döneminde uygulanacak maliye politikasının amacı, uzun dönemde Planın öngördüğü kaynak artışlarını sağlamak, ekonomik etkinlikleri Planın önceliklerine göre yönlendirmek ve gelir dağılımım iyileştirmek; kısa dönemde ise ekonominin genel dengesini korumaktır.

Gelir dağılımındaki dengesizlikleri ve vergilemedeki adaletsizlikleri gidermek, değişmez gelirliler üzerindeki vergi yükünü hafifletmek, vergi kayıp ve kaçakçı lığını önlemek, kamu harcamalarını sağlıklı kaynaklara dayandırmak, vergi sistemine gerekli esnekliği kazandırmak, yerel yönetimleri kendi öz kaynaklarına kavuşturmak ve gelir yönetimini yeniden düzenlemek, vergi politikasında gözetilecek temel esaslar olacaktır.

Vergi yargısının etkinliği artırılarak, zaman alıcı kademeleşme azaltılacak ve bağımsız vergi yargısının kurulmasına ilişkin çalışmalar sonuçlandırılacaktır.

Vergi denetimine özellikle kapsam ve yöntem yönünden ağırlık kazandırılacaktır.

Vergi yönetimi var olan koşullar ve gelişmeler gözetilerek yeniden düzenlenecek, bilgi işleme çalışmaları yoğunlaştırılarak sürdürülecek ve tamamlanacaktır. 
Mali danışmanlık kurumunun kurulması ve yükümlülerin eğitilmesine önem verilecektir.

Mal ve hizmetlerden alınan vergiler daha çok lüks tüketimi kapsayacak, maliyet enflasyonuna yol açmayacak ve dışsatımı özendirecek biçimde yeniden düzenlenecektir.

Yerel yönetimler temel işlevlerini görebilmelerini sağlayacak kendi öz kaynaklarına kavuşturulacak, böylece vergilerden çeşitli kamu idare ve kuruluşlarına pay verilmesi uygulaması sınırlandırılacaktır.

Vergi istisna ve bağışıklıkları yeniden gözden geçirilecek, ekonomik mali geçerliliği kalmamış olanların yürürlükten kaldırılması sağlanacaktır.

Vergi yasalarında gelir esnekliğini sağlama açısından, ölçü esasına göre vergilendirme yerine, vergi tekniğinin olanakları ölçüsünde, değer esasına göre vergilendirme temel ilke olacaktır (4.BYKP,1979: 264-265).

\subsection{BYKP'da Genel Hedefler ve Gerçekleşmeler (1985-1989)}

Beşinci Beş Yıllık Kalkınma Planı; 1985-1989 yıllarını kapsamaktadır.

Strateji'de belirlenen esaslar çerçevesinde Beşinci Beş Yıllık Planın temel amaçları, hür, medeni ve güvenli bir ortamda Türk Milletinin refahının artırılması, verimlilik ve ihracat artışını teşvik eden, mevcut birikimi değerlendiren ve geliştiren, tarımsal gelişme potansiyelini ve millî savunma gereklerini gözeten bir yapı içinde sınai üretimin payının yükseltilmesi, istihdamın artırılması, genç işsizliğinin azaltılması, gelir dağılımının düşük gelirli gruplar lehine değiştirilmesi, hür, medeni ve güvenli bir ortamda Türk Milletinin refahının artırılmasıdır (5.BYKP,1985: 1).

Planda yer alan vergi politikalarına ilişkin tespitler ve hedefler ise özetle aşağıdaki şekildedir.

Beşinci Plan döneminde toplam kamu gelirlerinin yılda ortalama yüzde 5,7 artırılması hedef alınmıştır. Plan dönemi başında 2.929,5 milyar lira olarak tahmin edilen toplam gelirler, Planın son yılında 3.868,6 milyar liraya ulaşacaktır.

Plan döneminde vasıtasız vergilerin, yılda ortalama yüzde 6,8 arttırılması öngörülmüştür, öte yandan vasıtalı vergiler ile servet vergileri için öngörülen yıllık ortalama artış ise sirasıyla, yüzde 6,2 ve yüzde 6,3 'tür. Toplam vergi gelirlerinin plan döneminde yılda ortalama yüzde 6,6 oranında artması vergi idaresinin daha etkin bir biçimde çalışarak vergi kayıplarını asgarî düzeye indirmesine bağlıdır.

Vasitasız vergiler Gelir ve Kurumlar Vergisini, servet vergisi ise sadece Veraset ve İntikal Vergisini kapsamaktadır. Servet vergisi ile vasıtasız kapsamına girmeyen diğer vergiler ise vasıtalı vergiler başlığı altında toplanmıştır.

Plan döneminde faktör gelirlerinin yüzde 6,3 oranında artırılması hedef alınmıştır. Vergi dışı normal gelirler ise aynı dönemde yüzde 0,7 dolayında azalacaktır.

Sosyal güvenlik müesseselerinin Plan döneminde kaynak açığı vereceği tahmin edilmektedir. Nitekim 1984 y1lında 23,5 milyar lira olan Sosyal Fonlardaki açık 1989'da 43,3 milyar liraya ulaşacaktır. 
1984 yllında toplam kamu gelirlerinin yüzde 68,1'ini vergiler, yüzde 9,7'sini vergi dışı normal gelirler, yüzde 11,3'ünü faktör gelirleri, yüzde 11,7'sini dış borçlanma oluştururken 1989 y1lında vergilerin toplam gelirler içindeki payı yüzde $70,8^{\prime}$ e, faktör gelirlerinin payı yüzde 11,6'ya yükselecek; vergi dışı normal gelirlerin payı yüzde 7,1'e, dış borçlanmanın payı ise yüzde 10,0'a düşecektir.

Kamu hizmetlerinin her kademesinde israf önlenecek ve tasarrufa riayet edilecektir.

Kamu gelirlerine gelişen ekonomik faaliyetleri kavrayacak bir esneklik kazandırılacaktır.

Vergiler, kurumlaşmayı, tasarrufu ve yatırımları teşvik edecek bir araç olarak kullanılacaktır.

Vergi idaresi reorganize edilecek; otomasyon artırılarak mevcut personel ile daha etkili hizmet verilmesi sağlanacaktır.

Vergi sistemi sadeleştirilerek, kolay anlaşır ve adil hale getirilecek, ihtilafların asgari hadde indirilmesi ve vergi kayıplarının azaltılması yönünde gerekli tedbirler alınacaktır.

Ödeme gücü olan fert ve sektörlerin vergi adaleti prensiplerine göre vergilendirilmeleri sağlanacaktır.

Katma değer sistemine geçilecektir.

Vergi sisteminde ölçü esâsına göre vergilendirme yerine, vergi tekniğinin imkânları ölçüsünde değer esasına geçilecektir denilmektedir (5.BYKP,1985: 2234)

1984 yılında kabul edilen ve 1985 yılında uygulanmaya başlanan Katma Değer Vergisi Türk vergi sisteminde yalnızca 1980'li yılların değil, bütün cumhuriyet tarihinin en önemli yasalarından biridir. Katma Değer Vergisi, ihraç edilen malların içerdiği dolaylı vergilerin mahsup edilmesine imkân verdiği için, ihracata dayalı büyüme gerçekleştirmeye çalışan iktidar için uygulanması tercih edilen bir vergi olmuştur (Kirmanoğlu,2004: 76).

\subsection{BYKP'da Genel Hedefler ve Gerçekleşmeler (1990-1994)}

Altıncı Beş Yıllık Kalkınma Planı; 1990-1994 yıllarını kapsamaktadır.

Türk milletinin refah seviyesini açık toplum ve rekabete açık ekonomi ilke ve esasları doğrultusunda, hür ve güvenli bir ortamda yükseltmek VI. Beş Y1llık Planın temel amacıdır. Hızlı, dengeli ve istikrarlı bir kalkınma süreci içinde gelir dağılımını iyileştirmek, işsizliği, bölgesel ve yöresel gelişmişlik farklarını azaltmak Planın başlıca amaçları arasındadır.

Planda yer alan vergi politikalarına ilişkin tespitler ve hedefler ise özetle aşağıdaki şekildedir.

Plan döneminde toplam kamu gelirlerinin sabit fiyatlarla yılda ortalama yüzde 7,4 artırılması hedef alınmıştır. 1989 yılında 29.113,1 milyar lira olarak tahmin edilen toplam gelirler, Plan dönemi sonunda 41.558,2 milyar liraya ulaşacaktır. 
Plan döneminde sabit fiyatlarla vasıtasız vergilerin yılda ortalama yüzde 7,2 , vasıtalı vergilerin yüzde 7,7 ve servet vergilerinin yüzde 7,4 olarak artırılmas öngörülmüştür. Toplam vergi gelirlerinde Plan dönemi süresince hedeflenen yılda ortalama yüzde 7,5 artışa ulaşılması, vergi idaresinin daha etkin bir biçimde çalışarak vergi kayıplarının asgari düzeye indirilmesiyle sağlanacaktır.

Faktör gelirleri ve vergi dışı normal gelirlerin Plan döneminde yılda ortalama yüzde 7,1 oranında artırılması hedeflenmiştir.

Sabit fiyatlarla 1989 yılında toplam kamu gelirlerinin yüzde 69,6'sını vergiler, yüzde 9,7'sini vergi dış1 normal gelirler ve yüzde 20,7'sini de faktör gelirleri ve sosyal fonlar oluştururken, 1994'te aynı kalemlerin toplam kamu gelirleri içindeki paylarının sırasıyla yüzde 70,0 , yüzde 9,6 ve yüzde 20,4 olarak gerçekleşmesi öngörülmektedir.

Toplam kamu gelirlerinin GSMH içindeki payı sabit fiyatlarla 1989 yılında yüzde 28,1 İken, 1994 y1lında yüzde 28,6'ya yükselecektir.

1989 yılında sabit fiyatlarla kamu harcanabilir gelirinin 17.870,5 milyar lira olacağ gelirinin yılda ortalama yüzde 7,1 artarak 25.200,2 milyar liraya ulaşması hedeflenmektedir (6.BYKP,1990: 22).

Vergilerin; kurumlaşmayı, tasarrufu, yatırımları ve ihracatı teşvik edici özelliklerinden yararlanırken kaynak yaratma fonksiyonları da ihmal edilmeyecektir.

Vergi idaresinin, verginin süratli ve sağlıklı toplanmasına elverişli, kendi içinde bütünlüğü olan bir yapıya kavuşturulması sağlanacaktır. Vergi kayıp ve kaçağını önlemek ve vergi güvenliğini sağlamak amacıyla kurulan vergi istihbarat arşivinin etkinliği artırılacak ve vergi denetimi için bilgi akışı hızlandırılacaktır.

AT'ye yapılan tam üyelik başvurusu göz önünde bulundurularak, başlamış olan vergi uyum çalışmaları süratle yürütülecek, bu konuda araştırma ve eğitim faaliyetlerine ağırlık verilecektir.

Yeni vergi ihdas edilmesi veya vergi oranlarının artırılması yerine, vergilemede yatay ve dikey adalet ilkeleri de dikkate alınarak vergi tabanının yaygınlaştırılması, vergi kayıp ve kaçağının asgari seviyeye indirilmesi ve tahsilattaki verimliliğin artırılabilmesi yolundaki gayretler sürdürülecektir (6.BYKP,1990: 34).

Altıncı Plan döneminde çok sayıda vergi düzenlemesi yapılmasına rağmen vergi yükünde arzu edilen seviyeye ulaşılamamıştır. Sosyal güvenlik primleri dâhil vergi gelirlerinin GSYİH'ya oranı 1992 yılında ülkemizde yüzde 22,4 iken, OECD ortalaması yüzde 38,8 düzeyinde gerçekleşmiştir. Sosyal güvenlik primleri hariç tutulduğunda ise bu oranlar sırasıyla yüzde 17,9 ve yüzde $28,9^{\prime}$ dur.

Gelir üzerinden alınan vergilerin efektif yükü, 1993 yılında tahakkuk bazında yüzde 11 'dir. Bu oranın tarım kesiminde yüzde 2,7, tarım dışı maaş ve ücret gelirlerinde yüzde 16,9 kira gelirlerinde yüzde 0,4 faiz gelirlerinde yüzde 5,9 ve tarım dışı diğer faktör gelirlerinde ise yüzde 11,3 olduğu görülmektedir. 
1986-1991 döneminde kanuni kurumlar vergisi oranı yüzde 46 iken, efektif oran yüzde 26 civarında kalmaktadır. Bankalarda bu oran yüzde 10'lar seviyesine inmektedir.

Vergi tahsilatında arzu edilen gelişmenin sağlanamamasının başlıca nedenleri; vergisel teşviklerin yoğun olarak kullanılması sonucunda vergi matrahlarının erimesi, belge ve kayıt düzeninin yerleştirilememesi, yönetim ve denetim fonksiyonlarının işletilememesi sonucunda vergi kayıp ve kaçağının önemli boyutlara ulaşmış olmasıdır (7.BYKP,1995: 105-106).

\subsection{BYKP'da Genel Hedefler ve Gerçekleşmeler (1996-2000)}

YedinciBeş Yıllık Kalkınma Planı; 1990-1994 yıllarını kapsamaktadır.

Planda yer alan vergi politikalarına ilişkin tespitler ve hedefler ise özetle aşağıdaki şekildedir.

Vergi düzenlemesindeki amaç, kayıt dışı ekonominin vergi kapsamına alınması, iktisadi etkinliğin sağlanması ve yatırımların özendirilmesi ile vergi adaletinin gerçekleştirilmesidir. Vergi alanında temel strateji, $A B$ vergi politikası ve vergi yapısını dikkate alarak tüm ekonomik faaliyetleri kapsayan, üretim faktörleri üzerindeki vergi yükünü azaltan, tüketim vergilerine ağırlık veren, gayrimenkul rantlarını vergileyen bir sistem oluşturmaktır.

Vergi sisteminin, ücretliler üzerindeki vergi yükünü azaltan ve değişen şartlarda ekonominin rekabet gücünü dikkate alan bir yapıya kavuşması sağlanacaktır.

Plan döneminde, öncelikle vergi idaresi ve denetiminin daha etkin hale getirilmesi ve idarenin yeniden yapılandırılması sağlanarak vergi kayıp ve kaçağı asgari seviyeye indirilecektir.

Gelir, Kurumlar ve Katma Değer Vergisi Kanunlarında yeralan istisna ve muafiyetlerin yeniden gözden geçirilerek asgari seviyeye indirilmesi uygulamasına devam olunacak, yatırım teşviklerinin ise etkinliğinin artırılması sağlanacaktır.

Vergilemede kayıt düzenini bozan götürü vergilendirme bölgesel ve sektörel olarak Gelir Vergisi Kanunu'nda gerçek usule geçişin özendirilmesi suretiyle daraltılacaktır.

Vergi politikasının toplumun temel tercihleri ve ülkenin ihtiyaçları doğrultusunda yapılandırılması amacıyla, akademik kurumların, işçi-işveren kuruluşlarının ve özel kuruluş ve örgütlerin de katılımıyla, yetki ve sorumlulukları tanımlanmış Vergi İstişare Konseyi kurulacaktır.

Plan döneminde, vergi idaresinin güçlendirilmesi, kayıt ve belge düzeninin yerleştirilmesi ile birlikte vergi sisteminde öngörülen değişikliklerin gerçekleştirilmesi sonucunda, 1995 yılında yüzde 18,1 olan vergi gelirlerinin GSMH'ya oranı, 2000 yılında yüzde 20 seviyelerine çıkarılacaktır (7.BYKP,1995: 106-108).

Toplam kamu gelirlerinin GSMH'ya oranı 1995 yılında yüzde 20,9 iken, bu oran 1999 y1lında yüzde 25,4'e yükselmiştir. Kamu gelirlerinde sağlanan bu olumlu gelişmede, faktör gelirlerinin yanı sıra vergi gelirlerinde görülen sürekli 
artış önemli rol oynamıştır. Vergi gelirlerinin 1995 y1lında yüzde 17,2 olan GSMH'ya oranı sürekli artış göstererek 1999 yılında yüzde 21,9'a yükselmiştir (8.BYKP,2000: 7).

\subsection{BYKP'da Genel Hedefler ve Gerçekleşmeler (2001-2005)}

Uzun Vadeli Strateji ve Sekizinci Beş Yıllık Kalkınma Planı; 2001-2005 yıllarını kapsamaktadır.

Sekizinci Plan döneminin, toplumun yaşam kalitesinin yükseldiği, kesintisiz ve istikrarlı büyüme sürecine girildiği, Avrupa Birliği üyeliği sürecindeki temel dönüşümlerin gerçekleştirildiği, dünya ile bütünleşmenin sağlandığı ve ülkemizin dünyada ve bölgesinde daha güçlü, etkili ve saygin yer edindiği bir dönem olacağı ve insanımızın hak ettiği yaşam düzeyinin sağlanması amacıyla, gelir dağılımının düzeltilmesine ve yoksullukla mücadeleye, bölgesel gelişmişlik farklarının azaltılmasına önem verilecektir denilmektedir (8.BYKP,2000: 25).

Planda yer alan vergi politikalarına ilişkin tespitler ve hedefler ise özetle aşağıdaki şekildedir.

Vergi sistemi basit ve anlaş1lır hale getirilecek, yeterli ve etkin belge düzeni ve otokontrol mekanizmaları geliştirilecek, vergi kayıp ve kaçakları azaltılacak, verginin tabana yayılması sağlanacaktır. Vergi İdaresinin uygulama hizmet ve denetim gücünü arttırmak amaciyla tam otomasyon projesine büyük önem verilecek ve süratli bir şekilde tamamlanacaktır.

Tevkif suretiyle vergi alınmasından vazgeçilmeksizin, gelir vergisinin kişiselliği ve mali güce göre vergilendirme ilkelerini dikkate alan üniter vergilemeye ağırlık verilecektir.

İstisna, muafiyet ve vergi indirimi gibi vergi harcamaları ekonomik ve sosyal politikalar çerçevesinde yeniden düzenlenecek, vergi harcamaları yoluyla alınmasından vazgeçilen tutarlar bütçe kanunu kapsamında ayrıntılı bir şekilde raporlanacaktır.

Vergi affı uygulamasını gerektirmeyecek ortam oluşturulacak ve af beklentilerinin ortadan kaldırılmasını sağlayacak düzenlemeler gerçekleştirilecektir.

Mahalli idarelerin sağladıkları hizmetlerle ilişkili olan bazı vergi ve harçların bu idarelere devri sağlanacaktır.

$\mathrm{Bu}$ bağlamda, kamu vergi gelirlerinin GSMH'ya oran1, depremlere bağlı olarak uygulamaya konulan ek vergi ve vergi benzeri uygulamaların sona ermesiyle Plan dönemi sonunda 2000 yllına göre 0,5 puanlık bir düşüş kaydedecektir. Özelleştirme programına bağlı olarak faktör gelirleri gerileyecek, sosyal güvenlik kuruluşlarına yapılan transfer harcamalarının GSMH'ya oranı ise 2000 yllındaki yüzde 2,5'lik düzeyinden Plan dönemi sonunda yüzde 1,7 seviyesine düssecektir. Plan döneminin ilk iki y1lı sonunda yüzde 1,7 olarak gerçekleşmesi beklenen özelleştirme gelirlerinin GSMH içindeki payının tedricen azalarak Plan dönemi sonunda yüzde 0,1 olarak gerçekleşeceği tahmin edilmektedir (8.BYKP, 2000: 28-41) 
Türkiye ekonomisi VIII. Planın baz yılı olan 2000 yılında yüzde 7,4 oranında büyümüş ancak 2001 krizi neticesinde yüzde 9,5 oranında daralmıştır. Kriz sonrası dönemde ise kararlı bir şekilde uygulanan s1k1 maliye ve para politikaları sayesinde makroekonomik istikrarın sağlanması yönünde önemli adımlar atılmış ve yüksek büyüme performansı sağlanmıştır. Nitekim, 2002-2005 döneminde GSYİH y1llık ortalama yüzde 7,5 oranında büyümüştür. Bunun sonucunda, 2000 yılında 2.879 dolar olan kişi başına milli gelir, 2005 yılında 5.042 dolara yükselmiştir. Genel devlet gelirlerinin GSYIH'ya oranı ise 2000 yılında 40.4 iken 2005 yllında 44.1'e yükselmiştir.

Sekizinci plan döneminde vergi sisteminin daha etkin ve basit hale getirilmesi amacıyla gelir ve kurumlar vergisi oranları düşürülmüş, istisna ve muafiyetler daraltılmış, özel tüketim vergisi uygulamaya konulmuş, yatırım araçları üzerindeki farklı vergilendirme uygulamalarına son verilmiş, yatırım indiriminin üç y1llık bir geçiş süreci sonunda tamamen kaldırılmasına yönelik düzenleme yapılmış, kamu maliyesindeki iyileşmeden de faydalanılarak gelir vergisinde ve bazı sektörlerde katma değer vergisinde indirim gerçekleştirilmiş ve mali kesim üzerindeki aracılık maliyetleri azaltılmıştır. Ayrıca gelir idaresi yeniden yapılandırılmıştır (Kalkınma Bakanlığı 9.BYKP, 2006: 13-18).

\subsection{BYKP'da Genel Hedefler ve Gerçekleşmeler (2007-2013)}

Dokuzuncu Beş Yıllık Kalkınma Planı; 2007-2013 yıllarını kapsamaktadır.

Dokuzuncu Kalkınma Planı, "İstikrar içinde büyüyen, gelirini daha adil paylaşan, küresel ölçekte rekabet gücüne sahip, bilgi toplumuna dönüşen, AB'ye üyelik için uyum sürecini tamamlamış bir Türkiye" vizyonu ve Uzun Vadeli Strateji (2001-2023) çerçevesinde hazırlanmıştır. Dokuzuncu Kalkınma Planı, AB'ye üyelik sürecine katkı sağlayacak temel strateji dokümanı olarak tasarlanmıştır. Bu nedenle Plan dönemi AB mali takvimi dikkate alınarak 20072013 yıllarını kapsayacak şekilde 7 yıllık olarak belirlenmiştir. 28 Nisan 2005 tarihinde 5339 sayılı Yasa ile 2005 yılı sonunda tamamlanan VIII. Beş Yıllık Kalkınma Planının ardından, hazırlanacak yeni Planın Türkiye Büyük Millet Meclisine sunulması bir yıl ertelenmiş ve Dokuzuncu Kalkınma Planının 2007 yılında başlaması kararlaştırılmıştır (Kalkınma Bakanlığ 9.BYKP, 2006: 1-2).

Planda yer alan vergi politikalarına ilişkin tespitler ve hedefler ise özetle aşağıdaki şekildedir.

Türkiye ekonomisi son dönemde, yapısal reformların ve kararlı1ıkla uygulanan sıkı para ve maliye politikalarının etkisiyle istikrar ortamını sağlamış ve dünya ekonomileri arasında örnek gösterilen bir büyüme performansı göstermiştir. Dokuzuncu Kalkınma Planı döneminde, reform sürecine ve tavizsiz şekilde uygulanacak para ve sıkı maliye politikalarına devam edilmesi, bu büyüme performansının devam etmesini sağlayacaktır. Plan döneminde GSYİH'nın yıllık ortalama yüzde 7 oranında artması ve kişi başına gelirin 2013 yılında 10.100 dolar olarak gerçekleşmesi beklenmektedir. Böylece, AB'ye nominal yakınsama sürecinde de önemli mesafe kaydedilmiş olacaktır ve GSYIH'sı yaklaşık 800 milyar dolara ulaşacak olan Türkiye, dünyanın en büyük 17'inci ülkesi konumuna yükselecektir. 
Yapısal önlemler, ekonomik istikrar ve yüksek oranlı büyümenin Plan döneminde kamu finansmanı dengesi üzerinde olumlu etkileri olacağ 1 ve VIII. Plan döneminde yıllık ortalama yüzde 9 açık veren genel devlet finansman dengesinin GSYİH'ya oranının, faiz harcamalarındaki azalmanın da etkisiyle, dönem ortalaması olarak yüzde 1,6 fazlaya döneceği tahmin edilmektedir.

Vergi politikalarının temel amac1; mükellef haklarına saygılı, vergi kayıp ve kaçağını azaltan, mali güç ilkesine uygun şekilde vergi yükünün adil ve dengeli dağıtımını gözeten, kamu giderlerini karşılarken iktisadi etkinliği bozmayan bir vergi sistemine ulaşmaktır. Bu amaçla;

- Vergi kanunları yeniden gözden geçirilerek, mevzuat sadeleştirilecek ve daha etkin ve uygulanabilir hale getirilecektir. Vergi muafiyet ve istisnalar, ekonomik ve sosyal politikalar ile kamu finansmanı imkânları çerçevesinde yeniden değerlendirilecektir.

- Ekonomide karar alıc1lar için öngörülebilirliği sağlamak amacıyla vergi düzenleme ve uygulamalarında istikrar sağlanacaktır.

- Mükelleflerin gönüllü uyumunu artırmaya yardımcı olacak şekilde mükellef haklarına yönelik düzenlemeler yapılacaktır.

- Vergi tabanının genişletilmesi ve kayıtdışı ekonomiyle mücadele sonucunda oluşacak ilave kaynaklar, işlem vergileri başta olmak üzere vergi oranlarının ve sosyal güvenlik primlerinin indiriminde kullanılacaktır (Kalkınma Bakanlığı, 9.BYKP, 2006: 54-64).

Dokuzuncu Kalkınma Planının uygulanmaya başlandığı ilk yıllarda iç siyasi konjonktürdeki gelişmeler ve hemen sonrasındaki küresel kriz, Türkiye ekonomisini etkileyen önemli faktörler olmuştur. Küresel kriz nedeniyle artan belirsizlik, güven ortamını ve ileriye dönük beklentileri olumsuz etkilemiş, yatırım ve tüketim kararlarının ertelenmesine ve ekonomik faaliyetlerin yavaşlamasına yol açmıştır. Buna bağlı olarak, 2002-2006 döneminde yıllık ortalama yüzde 7,2 oranında artan GSYH, 2007-2012 döneminde yüzde 3,3 oranında büyümüştür. Plan döneminde yeni millî gelir serisi ve nüfus istatistiklerinde yapılan güncellemeye göre, kişi başına millî gelir 2012 yılında 10.504 dolar, cari GSYH ise 786 milyar dolar olarak gerçekleşmiştir (Kalkınma Bakanlığ 1, 10.BYKP, 2013: 19).

Genel devlet gelirlerinin GSYH'ya oranı, harcamalardaki artışları karşılamak amacıyla alınan ilave önlemler neticesinde artmış, 2009 yılında yüzde 34,2'ye, 2012 y1lında ise yüzde 37,3'e yükselmiştir. 2009 y1lında sosyal güvenlik primleri dâhil yüzde 24,7 olan toplam vergi yükü, 2012 yılında yüzde 27,6 seviyesinde gerçekleşmiştir. Vergi yükündeki 2,9 puanlık artışın 1,2 puanı sosyal güvenlik primlerinden, 1,7 puanı ise vergilerden kaynaklanmaktadır. Genel devlet gelir büyüklüğünde bir defalık gelirler de önemli rol oynamış; bu çerçevede, 6111 sayılı Kanun kapsamında kamu alacaklarının yeniden yapılandırılması, 2006 ve 2008 yıllarında gerçekleştirilen sosyal güvenlik prim afları ile 2012 yılında hayata geçirilen bedelli askerlik uygulaması önemli miktarda kaynak sağlamıştır. Ayrıca, Dokuzuncu Kalkınma Planı döneminde GSYH'ya oranla yıllık ortalama yüzde 0,6 büyüklügünde özelleştirme geliri elde edilmiş, orman vasfinı yitirmiş hazine arazilerinin satışına başlanmıştır (Kalkınma Bakanlığı, 10.BYKP, 2013: 73). 


\subsection{BYKP'da Genel Hedefler ve Gerçekleşmeler (2014-2018)}

Onuncu Beş Yıllık Kalkınma Planı; 2014-2018 yıllarını kapsamaktadır.

Onuncu Kalkınma Planı; yüksek, istikrarlı ve kapsayıcı ekonomik büyümenin yanı sıra hukukun üstünlügü, bilgi toplumu, uluslararası rekabet gücü, insani gelişmişlik, çevrenin korunması ve kaynakların sürdürülebilir kullanımı gibi unsurları kapsayacak şekilde tasarlanmıştır. Planda, ülkemizin ekonomik ve sosyal kalkınma süreci bütüncül ve çok boyutlu bir bakış açısıyla ele alınmış, insan odaklı kalkınma anlayışı çerçevesinde katılımcı bir yaklaşım benimsenmiştir.

Ülkemizin potansiyelini, bölgesel dinamikleri ve insanımızın yeteneklerini harekete geçirerek kalkınma sürecinin hızlandırılması amacıyla, yeniden şekillenen dünya ekonomisinde uluslararası işbölümü ve değer zinciri hiyerarşisinde Türkiye'nin konumunun aşamalı olarak üst basamaklara çıkarılması hedeflenmektedir (Kalkınma Bakanlığ1, 10.BYKP, 2013: 1).

Uzun vadeli kalkınma amacı, yeniden şekillenmekte olan dünyada milletimizin temel değerlerini ve beklentilerini esas alarak gerçekleştirilecek yapısal dönüşümlerle ülkemizin uluslararası konumunu yükseltmek ve halkımızın refahını artırmaktır. Bu çerçevede, 2023 yılında GSYH'nın 2 trilyon dolara, kişi başına gelirin 25 bin dolara yükseltilmesi; ihracatın 500 milyar dolara çıkarılması; işsizlik oranının yüzde 5'e düşürülmesi; enflasyon oranlarının kalıcı bir biçimde düşük ve tek haneli rakamlara indirilmesi hedeflenmektedir.

Planda yer alan vergi politikalarına ilişkin tespitler ve hedefler ise özetle aşağıdaki şekildedir;

Plan dönemi boyunca GSYH'ya oran olarak genel devlet gelirlerinin sabit tutulması, genel devlet harcamalarının ise bir miktar düşürülerek genel devlet açığının Plan dönemi sonunda yüzde 0,5 'e düşürülmesi hedeflenmektedir.

Plan döneminde, vergi yükünün adil dağılımının sağlanması ve GSYH'ya oranla ortalama yüzde 28,6 seviyesinde olması öngörülmektedir.

Vergiye gönüllü uyumun artırılması ve kayıt dışı ekonominin azaltılmasıyla sağlanacak ilave kaynaklar, işlem vergilerinin düşürülmesi başta olmak üzere üretim ve istihdamı teşvik ederek büyümeye katkı sağlayacak şekilde değerlendirilecektir.

Vergilemenin daha adil olmasını ve mali fonksiyonunu yerine getirmesini sağlayacak şekilde vergi tabanı genişletilecektir.

Vergi politikası, üretim faktörlerinin etkin dağılımını sağlamaya yönelik olarak kullanılacaktır. 539. Temel vergi mevzuatı; ekonomik ve sosyal politikalar çerçevesinde sade ve uyum sağlanabilir hale getirilecek şekilde yeniden yazilacaktır.

Elektronik ticarette vergi kaybının önlenmesine yönelik gerekli hukuki ve idari düzenlemeler hayata geçirilecektir.

Yasal düzenlemeler, kısa ve uzun dönem mali sonuçları hesap edilerek yapılacaktır (Kalkınma Bakanlığı, 10.BYKP, 2013: 75). 
2015 y1lında Türkiye ekonomisi OVP hedefiyle uyumlu bir şekilde yüzde 4,0 oranında büyümüştür.

2015 yılında Çin ve Hindistan hariç yükselen ekonomilerin ve gelişmekte olan ülkelerin ortalama büyüme hızı ise yüzde 1,8 ' dir

2015 y1lında genel devlet toplam gelir ve harcamaları 2014 yılına göre GSYH'ya oran olarak sırasıyla 1,4 puan ve 0,9 puan artmıştır. Bir önceki yıla göre kaydedilen önemli gelir artışının yaklaşık yarısı dolaylı vergiler diğer yarısı da sosyal güvenlik primi tahsilatları kaynaklı olmuştur. Faiz harcamalarındaki 0,1 puanlık azalışa rağmen gerçekleşen harcama artışında genel devlet cari giderleri, yatırımları ve transferler toplamının katkısı eşit ölçüde görülmektedir.

Bu çerçevede, 2015 yılında GSYH'ya oran olarak genel devlet açığı yüzde 0,1 ; genel devlet faiz dışı fazlası ise yüzde 2,7 olarak gerçekleşmiştir. 2016 yılında özelleştirme gelirleri dâhil genel devlet gelirlerinin bir önceki yıla göre 0,9 puan artarak GSYH'ya oranla yüzde 41,9 olması beklenmektedir.

$\mathrm{Bu}$ gelişmelere paralel olarak, genel devletin 2016 y1lında GSYH'ya oranla yüzde 1,9 açık vermesi, genel devlet faiz dışı fazlasının ise yüzde 0,6 seviyesinde gerçekleşmesi beklenmektedir. 2015 yılında yüzde 2,1 olan faiz harcamaları ve özelleștirme gelirleri hariç genel devlet fazlasının GSYH'ya oranının 2016 y1lında yüzde 0,1'e düşmesi, 2016 yılı program tanımlı genel devlet faiz dışı dengesinin ise yüzde 1,4 açık vermesi öngörülmektedir (Kalkınma Bakanlığı, Orta Vadeli Program 2017-2019, 2016: 3-5).

\section{Sonuç ve Değerlendirme}

Türkiye'de planlama fikri 1930'lu yıllarda hazırlanan sanayi planları ile başlamış, Devlet Planlama Teşkilatının kurulduğu tarihten günümüze kadar onadet Beş Yıllık Kalkınma Planı hazırlanmış ve uygulamaya konulmuştur.

1961 Anayasasında, "Sosyal ve Ekonomik Hükümler" başlı̆ğ altında, devlete kalkınma planları hazırlama görevi verilerek, ekonomide kamu kesimine ayrı bir yer verilmiş, planlama, anayasal zorunluluk haline gelmiştir. Böylece, ekonomide devletin üstlendiği görevleri icra eden KİT'lere belirli ödevler yüklenmiş, iktisadi ve sosyal hayata planlama düşüncesi egemen olmuş, planların icrası için de DPT kurulmuştur.

Kalkınma, var olmak isteyen her toplum için kaçınılmaz bir durumdur. Yüksek bir kalkınma hızı ancak iyi bir devlet yönetimiyle mümkün olabilir.

Planlamaların en belirgin özelliği ise kamu kesimi için emredici, özel kesim için yol gösterici nitelikte oluşudur. Planlı dönemde özel kesim ülkenin orta ve uzun vadeli amaçları doğrultusunda özendirici bir yaklaşımla yönlendirilmiş ve başlangıçta yeterince sermayesi bulunmayan bu kesim geliştirilmiş ve günümüzde güçlü yatırımlar yapabilecek hale getirilmiştir. 
Türkiye'de de Kalkınma Planları "ithal ikameci sanayileşme stratejisi” esas alınarak hazırlanmıştır. İthal ürünler karşısında rekabet gücü düşük yerli ürünler ithal kotaları ve gümrük duvarları ile korunmuştur. 1980'li yılların ortalarında başlatılan ihracat seferberliği ile birlikte "ihracata yönelik strateji" veya "ihracatı temel alan model" ile dışa açılım dönemi başlamıştır ve bu politika günümüze kadar devam etmiştir.

Türkiye'de vergi yapıs1 son 50 yılda büyük bir değişim göstermiştir. Siklıkla yaşanan ekonomik krizler ve bu krizler sebebiyle kamu kesiminin kısa vadede ihtiyaç duyduğu yüksek oranlardaki finansman ihtiyacına ilâve olarak $\mathrm{AB}$ ile devam eden üyelik süreci, küreselleşme ve beraberinde gelen uluslararası alandaki gelişmelerin ülkemiz vergi sisteminin şekillenmesinde önemli etkileri olduğu görülmektedir.

Vergileme politikası, özellikle gelişmekte olan ülkelerde maliye politikaları araçlarından biri olarak oldukça etkin bir mali araç olarak görülmektedir.

$\mathrm{Bu}$ çalışmada, kamu maliyesinin en önemli araçlarından biri olan kamu gelirlerine ilişkin olarak 1963 yılından itibaren 5 yıllık olarak hazırlanan 10 adet Kalkınma Planlarında Vergi' ye ilişkin hedefler ve gerçekleşmeler tarihsel seyri içerisinde ele alınarak uygulanan Vergi Politikaları incelenmiş ve konuya ilişkin tespitler yapılarak bazı önerilerde bulunulmuştur.

Türkiye'de 1963 yılından itibaren uygulanmaya başlanan planlı kalkınma döneminde, başta ekonomik büyüme olmak üzere, IMF'nin öteden beri önerdiği kamu harcamalarının kısılarak, vergilerin artırılması gibi sıkı maliye politikaları sonucu, ilk iki planda öngörülen hedeflere büyük oranda ulaşılmış ancak Türkiye'nin içinde bulunduğu bölgeden kaynaklanan Jeopolitik gerginlikler ve küresel ekonomide zaman zaman ortaya çıkan zayıflıklar nedeniyle özellikle 2000'li y1llara kadar Türkiye ekonomisinin temel makroekonomik büyüklüklerinde ve vergi politikalarında sorunlar devam etmiş̧tir.

Birinci ve İkinci Beş Yıllık Kalkınma Plan döneminde özellikle ekonomik büyüme ve vergiye ilişkin hedefler açısından hedeflere büyük ölçüde ulaşılmıştır,

Üçüncü Beş Yıllık Kalkınma Planı döneminde büyüme oranları bakımından hedefe yaklaşılmış, ancak vergi gelirleri açısından arzu edilen seviyede bir gelişme mümkün olmamıştır.1970 İstikrar Programı ile birlikte vergi sisteminde ve daha sonra kamu iktisadi teşebbüslerinin fiyatlarında olumlu düzenlemeler yapılmıştır. Spekülatif karakterli gelirlere yönelen yeni vergiler kabul edilmiş bazı vergilerin kapsamları genişletilmiş ve nispetleri arttırılmıştır. Bu değişikliklerin vergi adaleti yönünden nitelikleri genellikle olumludur.

Dördüncü Plan döneminde uygulanacak maliye politikasının amacı ise, uzun dönemde Planın öngördüğü kaynak artışlarını sağlamak, ekonomik etkinlikleri Planın önceliklerine göre yönlendirmek ve gelir dağılımım iyileştirmek; kısa dönemde ise ekonominin genel dengesini korumak olarak ifade edilmektedir.

Beşinci Beş Yıllık Planın temel amaçları,hür, medeni ve güvenli bir ortamda Türk Milletinin refahının artırılması,hür, medeni ve güvenli bir ortamda Türk Milletinin refahının artırılması olarak ifade edilmiştir.1984 yılında kabul edilen ve 1985 yılında uygulanmaya başlanan Katma Değer Vergisi, Türk vergi 
sisteminde yalnızca 1980'li yılların değil, bütün cumhuriyet tarihinin en önemli yasalarından biri olmuştur.

Altıncı Beş Yı1lık Kalkınma Planının temel amacı, hızlı, dengeli ve istikrarlı bir kalkınma süreci içinde gelir dağılımını iyileștirmek, ișsizliği, bölgesel ve yöresel gelişmişlik farklarını azaltmaktır. Plan döneminde çok sayıda vergi düzenlemesi yapılmasına rağmen vergi yükünde arzu edilen seviyeye ulaşılamamıştır. Vergi tahsilatında arzu edilen gelişmenin sağlanamamasının başlıca nedenleri; vergisel teşviklerin yoğun olarak kullanılması sonucunda vergi matrahlarının erimesi, belge ve kayıt düzeninin yerleştirilememesi, yönetim ve denetim fonksiyonlarının işletilememesi sonucunda vergi kayıp ve kaçağının önemli boyutlara ulaşmış olmasıdır.

Yedinci Beş Yıllık Kalkınma Planındaki temel amaç ise, kayıt dışı ekonominin vergi kapsamına alınması, iktisadi etkinliğin sağlanması ve yatırımların özendirilmesi ile vergi adaletinin gerçekleştirilmesidir. Plan döneminde, vergi idaresinin güçlendirilmesi, kayıt ve belge düzeninin yerleştirilmesi ile birlikte vergi sisteminde öngörülen değişikliklerin gerçekleştirilmesi sonucunda, Vergi gelirlerinin 1995 y1lında yüzde 17,2 olan GSMH'ya oranı sürekli artış göstererek 1999 yılında yüzde 21,9'a yükselmiştir.

Sekizinci Plan döneminde ise, vergi sisteminin basit ve anlaş1ır hale getirileceği, yeterli ve etkin belge düzeni ve otokontrol mekanizmaları geliştirilerek, vergi kayıp ve kaçaklarının azaltılacağı, verginin tabana yayılmasının sağlanacağ 1 ifade edilmektedir. Sekizinci plan döneminde vergi sisteminin daha etkin ve basit hale getirilmesi amaciyla gelir ve kurumlar vergisi oranları düşürülmüş, istisna ve muafiyetler daraltılmış, özel tüketim vergisi uygulamaya konulmuş, gelir idaresi yeniden yapılandırılmıştır. Kriz sonrası dönemde ise kararlı bir şekilde uygulanan sıkı maliye ve para politikaları sayesinde makroekonomik istikrarın sağlanması yönünde önemli adımlar atılmış ve yüksek büyüme performansı sağlanmıştır. Nitekim 2002-2005 döneminde GSYIH yıllık ortalama yüzde 7,5 oranında büyümüştür. Bunun sonucunda, 2000 y1lında 2.879 dolar olan kişi başına milli gelir, 2005 yılında 5.042 dolara yükselmiştir. Genel devlet gelirlerinin GSYIH' ya oranı ise 2000 yılında 40.4 iken 2005 yılında 44.1'e yükselmiştir.

Dokuzuncu Kalkınma Plandönemi AB mali takvimi dikkate alınarak 20072013 yıllarını kapsayacak şekilde 7 yıllık olarak belirlenmiştir. Dokuzuncu Kalkınma Planının uygulanmaya başlandığı ilk yıllarda iç siyasi konjonktürdeki gelişmeler ve hemen sonrasındaki küresel kriz, Türkiye ekonomisini etkileyen önemli faktörler olmuştur. Küresel kriz nedeniyle artan belirsizlik, güven ortamını ve ileriye dönük beklentileri olumsuz etkilemiş, yatırım ve tüketim kararlarının ertelenmesine ve ekonomik faaliyetlerin yavaşlamasına yol açmıştır. Buna bağlı olarak, 2002-2006 döneminde yıllık ortalama yüzde 7,2 oranında artan GSYH, 2007-2012 döneminde yüzde 3,3 oranında büyümüștür.Plan döneminde yeni millî gelir serisi ve nüfus istatistiklerinde yapılan güncellemeye göre, kişi başına millî gelir 2012 yılında 10.504 dolar, cari GSYH ise 786 milyar dolar olarak gerçekleşmiştir. Genel devlet gelirlerinin GSYH'ya oranı, harcamalardaki artışları karşılamak amacıyla alınan ilave önlemler neticesinde artmış, 2009 yılında yüzde 34,2'ye, 2012 yılında ise yüzde 37,3'e yükselmiştir. 
Onuncu Kalkınma Planında ülkemizin ekonomik ve sosyal kalkınma süreci bütüncül ve çok boyutlu bir bakış açısıyla ele alınmış, insan odaklı kalkınma anlayışı çerçevesinde katılımcı bir yaklaşım benimsenmiştir. Bu çerçevede, 2023 yılında GSYH'nın 2 trilyon dolara, kişi başına gelirin 25 bin dolara yükseltilmesi; ihracatın 500 milyar dolara çıkarılması; işsizlik oranının yüzde 5'e düşürülmesi; enflasyon oranlarının kalıcı bir biçimde düşük ve tek haneli rakamlara indirilmesi hedeflenmektedir.

2015 yılında Türkiye ekonomisi OVP hedefiyle uyumlu bir şekilde yüzde 4,0 oranında büyümüştür.

2015 yılında Çin ve Hindistan hariç yükselen ekonomilerin ve gelişmekte olan ülkelerin ortalama büyüme hızı ise yüzde 1,8 olmuştur.

2015 y1lında genel devlet toplam gelir ve harcamaları 2014 yılına göre GSYH'ya oran olarak sırasıyla 1,4 puan ve 0,9 puan artmıştır.

Ülkemizin son y1llarda ortaya koyduğu ekonomik büyümenin vergi sistemimizde yapılacak düzenlemelerle birlikte sürekli kılınması ve daha da ileri götürülmesi; kalkınmanın sağladığı faydaların toplumun tamamına daha adil bir biçimde yansıtılabilmesi için vergi bilincinin geliştirilerek vergi yükünün daha adil bir şekilde dağıtılması amaçlanmalıdır.

Vergileme gücü asla yok etme gücü olmamalı; ekonomiye vergilemeyle müdahale en aza indirilmeli, yapısal değişim fiskal amaçların önünde olmalıdır. Vergi yapısı, ekonomik değişimleri kavrayacak esneklikte olmalıdır. Dolayısıyla vergi yükünün arttırılması yerine optimal vergi yükü arayışlarına yönelinmelidir. Vergi yükünün yayılı olması, tabanın genişlemesi yalnız vergi adaleti açısından değil, tarafsızlık ilkesiyle ulaşılmak istenen amaçlar açısından da zorunludur.

Uygulanan kararlı politikalar neticesinde kamu kesimi dengelerinde çok önemli iyileşmelerin sağlandığı son yıllarda, vergi politikalarının tasarlanmasında; vergilemede adalet, eşitlik, istikrar ve öngörülebilirliğin güçlendirilmesi yanında cari açıkla mücadele, ekonomide rekabet gücünün desteklenmesi ve kayıt dişı ekonomik faaliyetlerle mücadele edilmesi gibi ekonomik ve sosyal önceliklerin öne çıktı̆̆ görülmektedir.

Ekonomik büyüme ve kalkınmanın gerçekleşme imkânı yatırım hacmine bağlıdır. Bununla birlikte vergi, mahiyeti itibariyle de ekonomik büyüme ve kalkınma üzerinde bir ölçüde etkili olur. Vergiler, gelir üzerinden alındığından, tüketim ve tasarruf hacmini etkiler. Vergiler yoluyla tasarruf hacminde meydana gelen azalmanın, sermaye birikimi ve yatırımlar üzerinde olumsuz etkilere yol açması; özel kesimin yatırım hacmini daraltarak ekonomik kalkınma hızının planda öngörülen hedefe ulaşılmasını engeller. Vergi yolu ile özel kesimden kamu kesimine aktarılan fonların kamu kesiminde yatırıma tahsis edilmesi halinde toplam yatırım hacminde azalma meydana gelmez. Ancak bunun için vergi oranlarının saptanmasında ve vergi kaynaklarının seçiminde toplam tasarruf hacmini en az etkileyecek yöntemlerin kullanılmasına dikkat edilmelidir.

Türkiye'de uygulanan vergi politikası kapsamında; Anayasamızın 73.maddesinde de belirtildiği üzere vergi, bireylerin ödeme gücüne göre ve gelir, servet ve harcamaları üzerinden alınmakla birlikte, vergi tahsilatı esas itibarıyla, 
stopaj yoluyla tahsil edilen gelir vergisi ile harcama üzerinden alınan KDV'ye dayanmaktadır. Türkiye'de vergi sisteminin dolaylı vergiler ağırlıklı olması, beyana dayalı bir sistem haline gelememesi, istisna, muafiyet ve vergi harcamalarının yaygın olması, halka açık şirketlerin az, küçük aile şirketlerinin yaygın olması nedeniyle kayıt dışı ekonominin yüksek düzeylerde olması vergi politikalarının başarısızlığına yol açmaktadır.

Önümüzdeki süreçte ilk olarak yapılması gereken, vergi sistemimiz içerisinde dolaylı- dolaysız vergi gelirlerinin dağılımının düzeltilmesi ve kayıt dışı ekonominin boyutunun azaltılmasidır.

Ekonomik kalkınmayı sürdürülebilir kılma yolunda vergi politikaları, teknolojiyi, Ar-Ge ve inovasyonu, yenilenebilir enerjileri ve enerji verimliliğini desteklemelidir. Sürdürülebilirlik anlayışının yerleşmesinde temel etken olan eğitim hizmetleri ise teşvik edilmeye devam edilmelidir.

Türk Vergi Sisteminin Güçlü ve Zayıf Yönlerini aşağıdaki şekilde ifade etmek mümkündür.

Güçlü Yönleri;

- Vergi yapısı gelişmiş ülkelerle benzerlik göstermektedir.

- Vergi oranları gelişmiş ülkelere göre düşüktür.

- Vergi mevzuatı günümüzün koşullarına göre yenilenmektedir.

- Gerektiğinde hızlı ve etkin vergisel tedbirler alınabilmektedir.

- Kayıt Dışı Ekonomi ile istisna, muafiyet ve indirimler yüzünden vergi dışı kalan alanlar nedeniyle önemli bir vergilendirilebilir kapasite bulunmaktadır.

- Gelişen bilişim teknolojisinin vergi sistemine entegrasyonu sağlanmakta

olup, geliştirilen projelerle etkinlik artırılmaktadır. mevcuttur.

- Vergisel deneyimi yüksek personel yapısına sahip bir vergi idaresi

\section{Zayıf Yönleri;}

- Vergi mevzuatında sürekli değişiklikler yapılmaktadır.

- Kayıt dışı ekonomi ile istisna, muafiyet ve indirimler nedeniyle vergilendiril(e)meyen alanlar vergi sistemini ve vergi adaletini bozmakta, vergiye uyumu zorlaştırmaktadır.

- Vergi mevzuatı karmaşık bir yapıya sahiptir.

- Dolaylı vergilerin vergi gelirleri içindeki oranının yüksekliği vergilendirmede adalet ilkesini zedelemektedir.

- Gelir Vergisi, Kurumlar Vergisi ve KDV dar bir mükellef tabanı üzerine yoğunlaşmıştır.

- Vergi denetiminde etkinlik sağlanamamıştır. 
- Vergi cezaları ve uygulamaları caydırıcı nitelikte değildir.

- Kamu yönetimi ve kamu harcamalarında etkinliğin sağlanamaması vergiye karşı direnci artırmaktadır.

- Vergi bilinci zayıftır.

- Yerel yönetimlerin vergi gelirleri yeterli seviyede değildir.

- Vergileme işlemlerinde bürokrasi fazladır.

- Otokontrol müesseseleri yetersizdir.

- Uzlaşma müessesesi amacını aşmış ve af niteliğine dönüşmüştür.

- Ücret gelirleri vergilemesi istihdam vergisi niteliğine dönüşmüştür.

\section{Kaynaklar}

Akdoğan, Abdurrahman.,(2009), Kamu Maliyesi, Gazi Kitabevi, Ankara

Aydın, Fazıl.,(2009), Hükümet Programları ve Kalkınma Planlarında Maliye Politikası, Gelirler Kontrolörleri Derneği Yayını, Ankara

Beş Yıllık Kalkınma Planları.,(2016), http://www.kalkinma.gov.tr/Pages/BesYillik KalkinmaPlani.aspx

DPT, (1963), Birinci Beş Yıllık Kalkınma Planı (1963-1967), DPT Yayını, Ankara

DPT, (1967), İkinci Beş Yıllık Kalkınma Planı (1963-1967), DPT Yayını, Ankara

DPT, (1972), Üçüncü Beş Yıllık Kalkınma Planı (1973-1977), DPT Yayını, Yayın No:1664, Ankara

DPT, (1979), Dördüncü Beş Yıllık Kalkınma Planı (1979-1983), DPT Yayını, Ankara

DPT, (1985), Beşinci Beş Yıllık Kalkınma Planı (1985-1989), DPT Yayını, Yayın No:1974, Ankara

DPT, (1990), Altıncı Beş Yıılık Kalkınma Planı (1990-1994), DPT Yayını, Yayın No:2190, Ankara

DPT, (1995), Yedinci Beş Yıllık Kalkınma Planı(1996-2000), DPT Yayını, Ankara

DPT, (2000), Uzun Vadeli Strateji ve Sekizinci Beş Yıllık Kalkınma Planı (20012005), DPT Yayını, Ankara

Eker, Aytaç., Altay, Asuman ve Sakal, Mustafa.,(1996), Maliye Politikası, Takav Matbaacilik,

Gencel, Ufuk-Kuru Elif.,(2012), "Vergi Kültürü ve Vergi Politikaları Etkileşimi: Türkiye Değerlendirmesi”, Yönetim Bilimleri Dergisi, Cilt:10, Sayı:20, İzmir

Güner, Agah Oktay.,(1978), “Türkiye'nin Kalkınması ve İktisadi Devlet Teşekkülleri”, Damla Yayınevi, İstanbul 
Yalova Sosyal Bilimler Dergisi

Kalkınma Bakanlığı, (2016),Orta Vadeli Program(2017-2019)

Kalkınma Bakanlığı, (2006), Dokuzuncu Beș Yıllık Kalkınma Planı(2007-2013), 1 Temmuz 2006 ve 26215 sayılı Resmi Gazete, Ankara

Kalkınma Bakanlığı, (2013), Onuncu Beş Yıllık Kalkınma Planı(2014-2018), Ankara

Kalkınma Bakanlığı.,(2014), Bölgesel Gelişme Ulusal Stratejisi (2014-2023), "Daha Dengeli Topyekün Kalkınma", Bölgesel Gelişme ve Yapısal Uyum Genel Müdürlüğü

Kalkınma Bakanlığı.,(2014),Vergi Ö.İ.K. Raporu, Ankara

Karg1,Veli.,Özuğurlu H. Yasemin.,(2007), “Türkiye'de Küreselleşmenin Vergi Politikaları Üzerine Etkileri: 1980-2005 Dönemi”, Celal Bayar Üniversitesi İktisadi ve İdari Bilimler Fakültesi Dergisi,14/1

Kirmanoğlu, Hülya.,(1994), "Türkiye'de Vergi Reformları, Siyasal İktidarlar ve İktisat Politikaları", Maliye Araştırma Merkezi Konferansları, Cumhuriyet'in 70. Y111 Özel Say1s1, (36. Seri, Y1l 1994, İstanbul Üniversitesi, İktisat Fakültesi, Maliye Araştırma Merkezi Yayınları, No. 3891/551-78, İstanbul Üniversitesi Basımevi ve Film Merkezi), İstanbul

Korkmaz, Esfender., (1982), Vergi Yapısı ve Gelişimi, İstanbul Üniversitesi İktisat Fakültesi Yayınları No:2989/489, Gür-ay Matbaası, İstanbul

Nadaroğlu, Halil.,(2000), Kamu Maliyesi Teorisi, Beta Yayınc1lı, İstanbul

Önder, İzzettin., (2003), "Kapitalist İlişkiler Bağlamında ve Türkiye'de Devletin Yeri ve İşlevi”, Köse, A.H. Şenses, F. ve Yeldan, E.(der.), Küresel Düzen: Birikim, Devlet ve Sınıflar içinde, İletişim Yayınları, Ankara

Öner,Şerif-Yıldırım Uğur.,(2002),“1963’den 2002’ye.Kalkınma Planlarında Türk Yerel Yönetimlerinin Dönüşümü” ,Uludağ Üniversitesi İ̈BF Dergisi, Cilt XXI, Say 12

Özdemir, Volkan.,(2014),Türkiye'de Planlı Kalkınma Deneyimleri, Marmara Üniversitesi

Siverekli Demircan, Esra.,(2003) "Vergilendirmenin Ekonomik Büyüme ve Kalkınmaya Etkisi", Erciyes Üniversitesi İktisadi ve İdari Bilimler Fakültesi Dergisi, Sayı:21,Temmuz-Aralık 2003.

Takım, Abdullah., (2011),“Türkiye’de 1960-1980 Yılları Arasında Uygulanan Kalkınma Planlarında Maliye Politikaları", Maliye Dergisi, Sayı 160, Ocak-Haziran 2011.

Temiz Dilek.,(2008), Türkiye'de Vergi Gelirleri ve Ekonomik Büyüme İlișkisi:1960-2006 Dönemi, 2.Ulusal İktisat Kongresi, DEÜ İ̈BF İktisat Bölümü, İzmir

Türk, İsmail.,(1975), Maliye Politikası (Amaçlar-Araçlar) ve Çağdaş Bütçe Teorileri, 3.B., Doğan Yayınevi, Ankara 